\title{
TECOMEAE (BIGNONIACEAE) DA CADEIA DO ESPINHAÇO, MINAS GERAIS E BAHIA, BRASIL
}

\author{
L.G. Lohmann ${ }^{\text {1 }}$ \\ J.R. Pirani ${ }^{2}$ \\ Recebido em 18.07.95. Aceito em 12.03.96
}

RESUMO - (Tecomeae (Bignoniaceae) da Cadeia do Espinhaço, Minas Gerais e Bahia, Brasil), Este trabalho consiste num levantamento florístico dos representantes da tribo Tecomeae (Bignoniaceae) ocorrentes na Cadeia do Espinhaço, região serrana do interior de Minas Gerais e Bahia com cobertura vegetal constituída principalmente por campos rupestres. A tribo está representada na área por 17 espécies, distribuídas em 4 gêneros: Zeyheria (2 spp.), Tabebuia (6 spp.), Jacaranda (8 spp.) e Cybistax (1 sp.). São apresentadas chaves para os gêneros e espécies, descrições, ilustrações e comentários. J. oxyphylla é considerada sinônimo de J. caroba e J. morii é considerada sinônimo de J. ulei.

Palavras-chave: Bignoniaceae, Tecomeae, florística, Cadeia do Espinhaço.

ABSTRACT: (Tecomeae (Bignoniaceae) from the Espinhaço Range, Minas Gerais and Bahia, Brazil). This is a floristic survey of the Bignoniaceae, tribe Tecomeae, of the Espinhaço Range. This area includes a range of mountains, in the states of Bahia and Minas Gerais, with altitudes between $800-1800 \mathrm{~m}$ whose vegetation is mainly composed of "campos rupestres". The tribe is represented in the area by 17 species, distributed in 4 genera: Zeyheria ( $2 \mathrm{spp}$.), Tabebuia ( $6 \mathrm{spp}$.), Jacaranda ( $8 \mathrm{spp}$.) and Cybistax ( $1 \mathrm{sp}$.). Keys to genera and species, descriptions, illustrations and are presented comments. J. oxyphylla is reduced to the synonymy of $J$. caroba and $J$. morii is
reduced to the synonymy of $J$. ulei.

Key-words: Bignoniaceae, Tecomeae, floristics, Espinhaço Range,

\section{Introdução}

1. A Cadeia do Espinhaço

A Cadeia do Espinhaço (Fig. 1), também conhecida como Serra Geral (King 1956), compreende um grupo de serras entre os limites $20^{\circ} 35^{\prime} \mathrm{S}$ e $11^{\circ} 11^{\prime} \mathrm{S}$, com altitudes médias entre 800 e 1800 m e extensão total de cerca de 1100 km (Magalhães \footnotetext{
'Instituto de Biociências, Universidade de São Paulo. C.P. 11461 - 05422-970 - São Paulo, SP. Bolsista
de Iniciação Científica, CNPq.

2 Instituto de Biociências, Universidade de São Paulo. C.P. 11461 - 05422-970 - São Paulo, SP.
} 
1954). Limitada ao sul pela Serra de Ouro Branco, em Minas Gerais, e ao norte pela região de Juazeiro, na Bahia (Abreu 1984), este setor do escudo cristalino brasileiro constitui o divisor de águas entre os rios que correm para o São Francisco e os que se dirigem diretamente para o Oceano Atlântico (Moreira 1977).

Distingue-se na Cadeia um Setor Mineiro, cujo limite norte fica nas elevações isoladas na área de Monte Verde e Montezuma, separado do Setor Baiano (normalmente denominado Chapada Diamantina) por um considerável hiato de terrenos baixos (Fig. 1). Os imensos afloramentos rochosos de toda a Cadeia são muito antigos e resistentes aos processos de erosão diferencial, pois foram modelados geralmente em rochas silicosas, notadamente os quartzitos (Moreira 1977). Predominam na região solos arenosos e rasos (Joly 1970).

Segundo Galvão \& Nimer (1965), o clima pode ser incluído no tipo Cwb de Köppen (1931), clima mesotérmico com verões brandos e estação chuvosa no inverno, cuja temperatura média varia de $17,4-19,8^{\circ} \mathrm{C}$, sendo a temperatura média do mês mais quente inferior a $22^{\circ} \mathrm{C}$. A precipitação anual da região está em torno de $1500 \mathrm{~mm}$, com um período seco de 3 a 4 meses, coincidindo com o inverno, e um período úmido de 7 a 8 meses que vai de setembro a abril.

A vegetação é constituída principalmente por campos rupestres (Magalhães 1966), caracterizada por um estrato herbáceo contínuo onde se destacam arbustos e subarbustos, ou ainda arvoretas. Outras formações que lá ocorrem são as matas ciliares, capões, manchas de cerrado e numerosos brejos estacionais.

Vários estudos sobre a vegetação e flora de serras do Espinhaço foram publicados nos últimos anos, destacando-se Harley \& Simmons (1986), Gentry et al. (1987), Giulietti \& Pirani (1988), Meguro et al. (1994) e Pirani et al. (1994).

Os aspectos fundamentais que têm motivado os estudos botânicos e biogeográficos nesse conjunto orográfico brasileiro são:

a) o fato do Espinhaço constituir o centro de diversidade genética de numerosos gêneros de Compositae, Melastomataceae, Ericaceae, e mesmo de famílias inteiras como Velloziaceae, Eriocaulaceae e Xyridaceae, sendo estas últimas incomuns ou mesmo totalmente ausentes em outras formações brasileiras;

b) sua flora campestre muito rica, contendo elevado grau de endemismos, sejam eles paleo ou neo-endemismos;

c) a diversidade da paisagem, basicamente condicionada à topografia acidentada dos terrenos;

d) os interessantes padrões de distribuição geográfica das espécies, com vários tipos de disjunções, decorrentes do isolamento das serras que compõem a Cadeia e do fato desta, como um todo, ficar "ilhada" parcialmente dentro do domínio morfoclimático dos cerrados (o que se verifica com o setor mineiro do Espinhaço) e parcialmente dentro do domínio das caatingas (no setor baiano do Espinhaço), conforme já ressaltaram Giulietti \& Pirani (1988).

\section{Bignoniaceae}

As Bignoniaceae são dicotiledôneas com cerca de 113 gêneros e 800 espécies, 


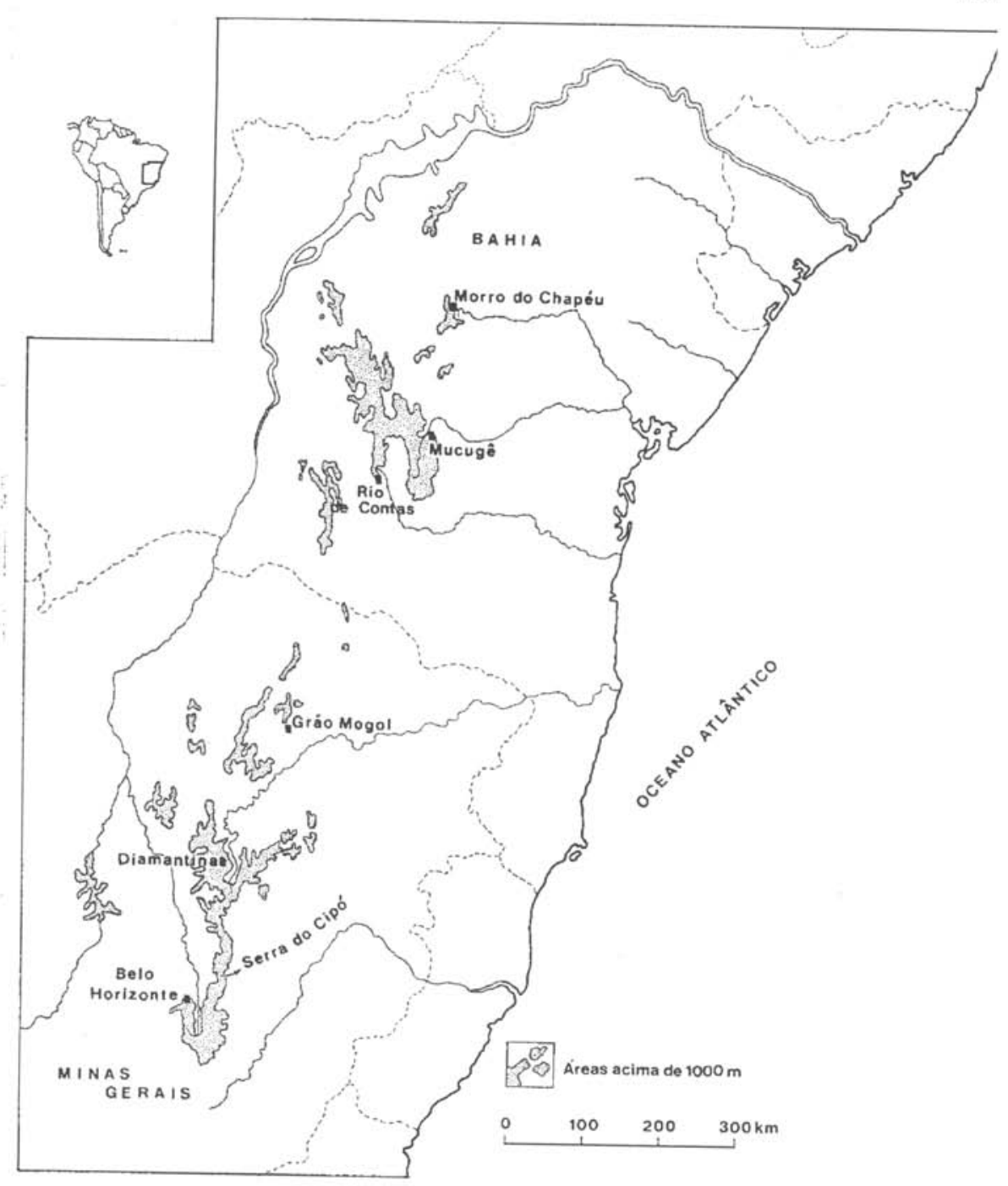

Figura 1. Localização da Cadeia do Espinhaço.

predominantemente neotropicais com poucas espécies distribuídas nas regiões temperadas (Gentry 1980). São plantas lenhosas, predominantemente lianas. As folhas geralmente são opostas e compostas. As flores são monóclinas, diclamídeas e simpétalas, de um modo geral vistosas. O androceu compõe-se de 4 estames didínamos, com anteras divaricadas e 1 estaminódio. A presença de um disco nectarífero ao redor do ovário é muito comum. O fruto pode ser uma cápsula ou indeiscente. As sementes são 
usualmente aladas.

Segundo Gentry (1980), a família está dividida em 8 tribos: Bignonieae, Colleae, Crescentieae, Eccremocarpeae, Oroxyleae, Schlegelieae, Tecomeae e Tourretieae, as quais diferenciam-se essencialmente pelo hábito e características de seus frutos.

Tecomeae é a segunda maior tribo de Bignoniaceae incluindo $34 \%$ das espécies do Novo Mundo distribuídas em 20 gêneros, 9 dos quais são encontrados no Brasil, sendo Tabebuia e Jacaranda os maiores. A maioria dos gêneros são arbóreos ou arbustivos. As folhas são usualmente opostas, raramente alternas, simples, digitadas, pinadas ou bipinadas. A inflorescência é terminal ou axilar, em tirso, tirsóide, botrióide, racemo ou reduzida a uma só flor. A polinização de suas flores é feita normalmente por abelhas, morcegos, pássaros ou borboletas. O cálice é cupular, às vezes espatáceo, reduzido e campanulado, raramente com 5 sépalas totalmente separadas. Os estames são 4, raramente 2, usualmente didínamos, comumente apresentando 1 estaminódio posterior; os grãos de pólen são simples ou em tétrades. O ovário bilocular tem duas placentas axiais em cada lóculo; o disco nectarífero é usualmente largo e conspícuo. O fruto típico da tribo é uma cápsula com deiscência perpendicular ao septo.

A tribo foi anteriormente os eada de modo bastante abrangente para a região neotropical por Gentry (1992).

\section{Objetivos:}

A importância das espécies da tribo Tecomeae como componentes dos campos rupestres, cerrados e matas da Cadeia do Espinhaço e os poucos dados existentes sobre a ocorrência das mesmas nesta área motivaram este estudo que teve por objetivo: o levantamento dos gêneros e espécies de Tecomeae na área, apresentação de descrições, ilustrações e chaves de identificação para os gêneros e espécies os eadas e a análise da distribuição geográfica dos gêneros e espécies da Cadeia do Espinhaço.

\section{Material e métodos}

Procedeu-se inicialmente a um levantamento bibliográfico das publicações sobre a família, execução de expedições de coleta em diversas serras da Cadeia do Espinhaço e estudo do acervo do herbário SPF, que abriga uma excelente coleção de plantas dessa região. Posteriormente foram também os eados espécimes dos herbários SP, R e RB, e em visita aos herbários BHCB, BHMH, BM, BR, K, MO, NY, P e US a primeira autora pode examinar coleções históricas e fazer comparações com espécimes-tipo. Nas citações do material eos eado, as siglas CFSC e CFCR correspondem, respectivamente, a Coleção Flora da Serra do Cipó, e Coleção Flora de Campos Rupestres.

Foi utilizada como obra básica durante todo o trabalho a monografia de Gentry (1992), porém várias das circunscrições taxonômicas propostas pelo autor foram questionadas, tendo sido observadas algumas divergências no tratamento morfológi- 
co, notadamente com referência à tipologia de inflorescências, adotando-se no presente trabalho conceitos de Weberling (1989), segundo a escola de Troll.

As chaves de identificação para gêneros e espécies bem como descrições de espécies foram elaboradas apenas com base no material proveniente da Cadeia do Espinhaço e portanto incluem apenas a variabilidade morfológica intra e inter-específica encontrada na região. No entanto, as descrições dos gêneros são amplas, incluindo também a variabilidade não encontrada na Cadeia do Espnhaço. O material examinado é citado de acordo com a posição geográfica, indo de norte a sul e de leste a oeste.

\section{Resultados}

Chave para os gêneros de Tecomeae da Cadeia do Espinhaço

1. Folhas pinadas ou bipinadas; corola azul, arroxeada, lilás ou vinácea; estaminódio glandular-pubescente, alongado, excedendo os estames; fruto achatado

Jacaranda

1'. Folhas digitadas; corola amarela, ocrácea ou verde clara (nas espécies do Espinhaço); estaminódio glabro, pubérulo ou piloso na região de inserção dos estames, reduzido, mais curto que os estames; fruto volumoso

2. Cálice profundamente 2-4-lobado; corola densamente tomentosa externamente; cápsula arredondada ou ovóide, muricada

2’. Cálice 5-denteado; corola glabra ou pubérula externamente; cápsula linear ou oblonga, lisa ou costada

3. Cálice coriáceo, lobos com ápice agudo ou arredondado; cápsula linearcilíndrica, coriácea, lisa, pubescente

3'. Cálice membranáceo, lobos com ápice visivelmente acuminado; cápsula oblonga, lenhosa, costada, glabra a minutamente lepidota Tabebuia Cybistax

\section{Cybistax Mart. ex Meisner.}

Árvores ou arbustos. Folhas digitadas, 5-7-folioladas, persistentes, raque nunca alada. Inflorescência tirsóide, terminal. Cálice campanulado, conspicuamente 5denteado, membranáceo, minutamente lepidoto, às vezes inconspicuamente pubérulo, lobos com ápice visivelmente acuminado; corola verde-clara, tubular-campanulada, membranácea, face externa pubérula, interna quase glabra ou raramente pubérula na base; anteras bitecas, glabras, estaminódio reduzido, glabro; ovário ovóide-oblongo, minutamente lepidoto-glandular; óvulos multisseriados; disco nectarífero anular. Cápsula oblonga, lenhosa, volumosa, com 12 costelas longitudinais, glabra a minutamente lepidota, margem plana. Sementes finas, com alas membranáceas.

Gênero neotropical monoespecífico.

\subsection{Cybistax antisyphilitica (Mart.) Mart., Syst. mat. med. bras. p. 66. 1843.} Figs. 2 A-C.

Árvore 2,0-3,5 m alt.; ramos glabros ou esparsamente pubérulos. Folhas 5folioladas; folíolos cartáceos, elípticos ou obovais, centrais medindo $7,0-9,0 \mathrm{~cm}$ 
compr., 2,3-2,7 cm larg. com peciólulos 0,5-1,2 cm compr., diminuindo progressivamente em direção à base, ápice acuminado, base cuneada ou atenuada, concolores, face abaxial lepidota, adaxial glabra ou com esparsos tricomas simples na axila da nervura principal, venação craspedódroma, margem inteira, suavemente revoluta; pecíolos 7,6-13,4 cm compr., glabros. Flores não vistas. Cápsula oblonga, castanho escuro a esverdeada, 11,3-24,0 cm compr., 4,2-5,3 cm larg., extremidades agudas ou acuminadas, minutamente lepidota.

Material examinado: BAHIA: Piatã, estrada Piatã-Abaíra, ca. $3 \mathrm{~km}$ de Piatã, col. W. Ganev 859, 14.VIII.1992, fr. (SPF). MINAS GERAIS: Grão-Mogol, próximo ao Córrego da Bonita, col. J. Prado et al., CFCR 12090, 29.V.1988, (SPF, MO, K); Lagoa Santa, col. Mello Barreto 9162, 28.IX.1937, fr. (BHMH); Santa Luzia, Borges, col. Mello Barreto 11202, 13.IX.1941, fr. (BHMH); Pico do Itabirito, col. W.A. Teixeira, 25.II.1995, fr. (BHCB 26502).

Segundo Gentry (1992), ocorre do Brasil extra-amazônico até o Paraguai, Bolívia, norte da Argentina e regiões mais secas da encosta oriental dos Andes peruanos. Ocorre próximo ao nível do mar até 1800 (-2400) m s.m. Na Cadeia do Espinhaço ocorre em carrascos associados aos campos rupestres, em solo arenoso. Foi coletada com frutos em fevereiro, maio, agosto e setembro.

\section{Jacaranda Juss.}

Árvores, arvoretas, algumas vezes arbustos ou subarbustos com xilopódio. Folhas pinadas ou bipinadas, raramente simples, persistentes, raque comumente alada. Inflorescência tirsóide ou botrióide, terminal ou axilar. Cálice campanulado, 5-lobado ou 5-denticulado, lobos com ápice agudo, acuminado ou arredondado, consistência e pilosidade variáveis; corola azul, arroxeada, lilás ou vinácea, raramente branca, tubular-campanulada, membranácea, glabra a pubescente; anteras bitecas ou com 1 teca reduzida, glabras, estaminódio alongado, excedendo os estames, glandular-pubescente, principalmente no ápice e região mediana; ovário ovóide, glabro ou pubescente, óvulos ca. de 8 séries por lóculo; disco nectarífero anular. Cápsula oblonga, elíptica, obovada ou orbicular, achatada, lenhosa, glabra ou lepidota, margem comumente ondulada. Sementes finas, com alas membranáceas.

Gênero neotropical com 49 espécies no tratamento de Gentry \& Morawetz (1992). Na Cadeia do Espinhaço foram registradas 8 espécies.

Chave para as espécies de Jacaranda da Cadeia do Espinhaço

1. Cálice partido até a base; anteras monotecas; fruto com margem fortemente ondulada J.brasiliana

1'. Cálice inconspicuamente denteado ou partido até a metade; anteras bitecas; fruto com margem plana a suavemente ondulada

2. Folhas bipinadas

3. Folíolos fortemente bulados, com raque conspicuamente alada J.ulei

3'. Folíolos planos, com raque não alada, raramente estreitamente alada 
4. Árvore ou arvoreta; folíolos com margem denteada

5 . Folíolos concolores, glabros ou esparsamente pubescentes, margem suavemente denteada, não revoluta ou suavemente revoluta ..

5'. Folíolos discolores, densamente pubescentes, margem conspicuaJ. puberula mente denteada, fortemente revoluta J. pulcherrima 2'. Folhas pinadas

4'. Arbusto ou subarbusto; folíolos com margem inteira J. caroba

6. Folhas em roseta basal, dispostas em ramos comentrenós curtos; folíolos cartáceos, oblanceolados a obovais; inflorescência botrióide J. racemosa

6'. Folhas não rosuladas, dispostas em ramos com entrenós longos; folíolos coriáceos, obovais a oblongo-elípticos; inflorescência tirsóide 7 . Subarbusto; folíolos 5-9, com margem não revoluta; cálice curtamente denteado J. paucifoliolata

7 Arbusto ou arvoreta; folíolos 9-15, com margem revoluta; cálice partido até a metade J. irwinii

2.1. Jacaranda brasiliana (Lam.) Pers., Syn. pl. 2: 174. 1807.

Figs. $2 \mathrm{H}-\mathrm{K}$

Árvore ou arvoreta até 5,0 m alt.; ramos glabrescentes, com entrenós longos. Folhas bipinadas, com 15-21 folíolos de $1^{\text {\# }}$ ordem, raque estreitamente alada; folíolos de $2^{\mathrm{a}}$ ordem cartáceos, elípticos ou elíptico-lanceolados, planos, 0,8-1,5 cm compr., 0,3-0,5 cm larg., sésseis, ápice obtuso, base cuneada, concolores, face abaxial tomentosa e esbranquiçada, adaxial pubescente, venação não evidente, margem inteira, não revoluta. Inflorescência tirsóide, terminal. Cálice partido até a base, membranáceo, 0,2-0,4 cm compr., 0,3-0,4 cm larg., pubérulo; corola azul-arroxeada, tubo 2,6-4,4 cm compr., 0,8-1,7 cm larg. na região mediana, face externa pubérula, com esparsos tricomas glandulares, interna vilosa; anteras monotecas, uma das tecas reduzida a um apêndice; ovário glabro. Cápsula oblongo-elíptica, castanho-clara, 7,5-8,0 cm compr., 5,7-6,7 cm larg., glabra, margem fortemente ondulada.

Material examinado: MINAS GERAIS: Grão-Mogol, Vale do Rio Itacambiruçu, col. I. Cordeiro \& R. Mello-Silva, CFCR 10129, 05.IX.1986, fl. fr. (F, MBM, MO, SPF); Santa Luzia, Gorduras de Baixo, col. Mello Barreto 11207, 17.IX.1941, fl. (BHMH); col. Glaziou 14122, 25.VII.1982, fl. (R).

É característica dos cerrados, campos cerrados e florestas de galeria, ocorrendo do Mato Grosso e Minas Gerais até Pernambuco, Maranhão e sul do Pará, em regiões entre 200-1000 m s.m. (Gentry 1992). Na Cadeia do Espinhaço apenas três espécimes foram coletados, estes encontrados entre rochas e à beira rio. Foram coletados com flores em julho, setembro e novembro e frutos em novembro.

2.2. Jacaranda ulei Bur. \& K. Schum. in Mart., Fl. Bras. 8(2): 383. 1897.

Jacaranda morii A. Gentry, Phytologia 57: 247. 1985, syn. nov. 
Figs. 2 D-G

Tipos examinados: Jacaranda ulei Bur. \& K. Schum., São Paulo, Campos da Bocaina, col. Glaziou 8212, 8.I.1876, fl. (sintipo R); Jacaranda morii A.Gentry, Bahia, Andaraí, rodovia Andaraí-Mucugê, $20 \mathrm{Km} \mathrm{S}$ de Andaraí, col. Mori \& Benton 13114, 21.XII.1979, fl. (isótipo MO).

Subarbusto, arbusto ou arvoreta até $2,5 \mathrm{~m}$ alt.; ramos densamente pubescentes, com entrenós longos. Folhas bipinadas, com 11-17 folíolos de $1^{\mathrm{a}}$ ordem, raque conspicuamente alada; folíolos de $2^{\mathrm{a}}$ ordem coriáceos, oval-lanceolados, fortemente bulados, 0,8-3,1 cm compr., 0,3-0,8 cm larg., sésseis, ápice agudo, base cordada, discolores, face abaxial tomentosa e esbranquiçada, adaxial verde-oliva escuro, pubescente, venação não evidente, margem inteira, fortemente revoluta. Inflorescência tirsóide, terminal. Cálice verde, às vezes vináceo, cartáceo, ligeiramente partido, 0,7-1,3 cm compr., 0,3-0,5 cm larg., pubescente; corola vinácea, tubo 4,1-5,2 cm compr., 0,8-1,6 cm larg. na região mediana, face externa pubérula, com raros tricomas glandulares, interna glabra, com esparsos tricomas na região de inserção dos estames; anteras bitecas; ovário glabro. Cápsula orbicular, verde quando jovem, castanho escuro quando madura, 4,7-6,3 cm compr., 4,5-5,2 cm larg, glabra, margem plana.

Material examinado: BAHIA: Abaíra, 3-7 km de Catolés, na estrada para Inúbia, col. R.M. Harley; E. Nic Lughadha \& R.F. Queiroz, H.50547, 28.XII.1991, fl. fr. (CEPEC, HUEFS, K, SPF); Rio de Contas, col. B. Stannard et al., CFCR 6836, 13.XII.1984, fl. (K, SPF); idem, Pico das Almas, col. R.M. Harley \& B. Stannard 27099, 11.XII.1988, fl. (CEPEC, K, SPF); idem, Pico das Almas, col. R.M. Harley \& D.J.N. Hind 27259, 16.XII.1988, fl. (CEPEC, K, SPF). MINAS GERAIS: Serra do Caraça, caminho para Belchior, col. I.R. Andrade 10, 12.XII.1986, fl. (BHCB).

Esta espécie é muito característica pelos folíolos coriáceos, fortemente bulados e discolores, com a face abaxial verde-esbranquiçada e a adaxial verde-oliva escuro. Gentry \& Morawetz (1992), reconhecem J. morii A.Gentry como táxon distinto, principalmente pelos folíolos oblongo-ovais com a base subcordada, afirmando que em $J$. ulei estes são oblongo-elípticos com a base arredondada ou estreitamente cordada. Ainda segundo estes autores, J. morii teria uma distribuição disjunta em mata-de-cipó e cerrados da região de Rio de Contas, Bahia, e em vegetação arbustiva de Serra de Carajás, Pará, enquanto J. ulei ocorreria de Goiás e extremo noroeste de Minas Gerais a cerrados de Rio de Contas, Bahia. Contudo, eles próprios admitiram a possibilidade de J.morii e J.ulei representarem apenas formas extremas de uma espécie. No presente trabalho, em que pudemos analisar a maioria das coleções deste grupo os eadas por Gentry \& Morawetz (1992), inclusive tipos, constatamos que inflorescências, flores e frutos exibem um aspecto semelhante, em relação à forma, indumento e dimensões, e que a forma dos folíolos tem alta variabilidade, não se verificando as diferenças apontadas por aqueles autores. O exame de farto material proveniente da região de Rio de Contas (área onde J. morii e J. ulei ocorreriam simpatricamente) veio assegurar que apenas um táxon deve ser aqui reconhecido.

Nesta nova acepção, J. ulei fica então distribuída no centro de Goiás, noroeste de Minas Gerais, centro da Bahia e Serra de Carajás, Pará. Na Cadeia de Espinhaço, 


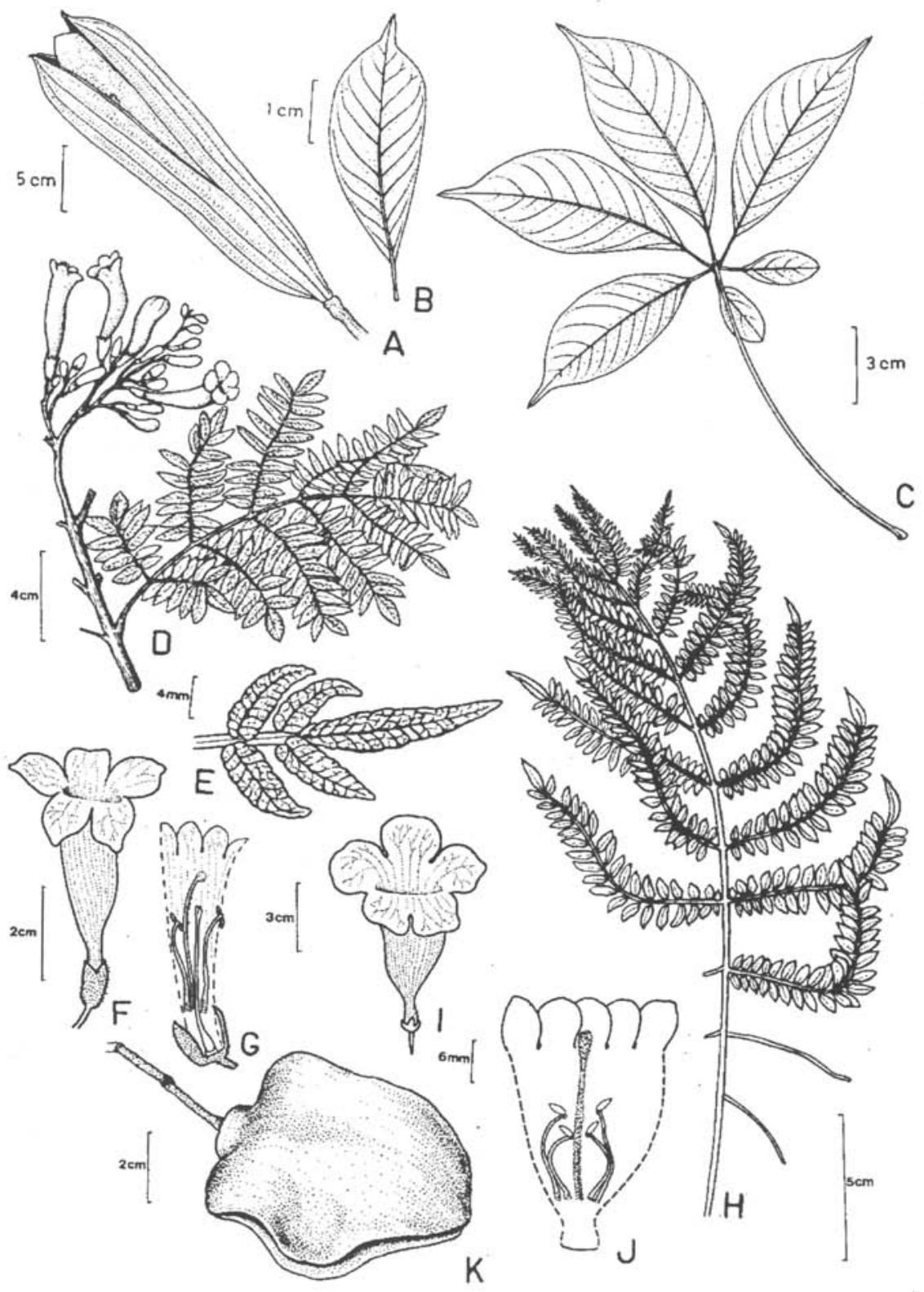

Figura 2. A-C: Cybistax antisyphilitica (Mart.) Mart. (CFCR 12090). A: Fruto; B: Folíolo; C: Folha. D-G: Jacaranda morii A. Gentry (Harley 27099). D: Ramo; E: Folíolos em detalhe; F: Aspecto geral da flor; G: Flor aberta. H-K: Jacaranda brasiliana (Lam.) Pers. (CFCR 10129). H: Folha; I: Aspecto geral da flor; J: Corola aberta; K: Fruto. 
foi encontrada em cerrado, campo e carrascal, entre 1000 e $1200 \mathrm{~m}$ s.m., florescendo em dezembro.

\subsection{Jacaranda puberula Cham., Linnaea 7: 550. 1832.}

Árvore ou arvoreta, 4-8 m alt.; ramos minutamente pubérulos, com entrenós longos. Folhas bipinadas, com 8-10 folíolos de $1^{\mathrm{a}}$ ordem, raque não alada; folíolos de $2^{\mathrm{a}}$ ordem cartáceos, obovais, elípticos ou estreitamente elípticos, planos, 2,4-4,0 cm compr., 0,8-1,9 cm larg., sésseis ou curtamente peciolados, ápice agudo, acuminado, arredondado ou obtuso, base cuneada, concolores, ambas as faces glabras ou esparsamente pubescentes, venação broquidódroma, margem suavemente denteada, não revoluta ou suavemente revoluta. Inflorescência tirsóide, terminal. Cálice vináceo, cartáceo, ligeiramente partido, 0,8-1,2 cm compr., 0,4-0,7 cm larg., pubérulo; corola roxa, esbranquiçaú ta região ventral do interior do tubo, tubo 4,2-5,5 cm compr., 1,2$1,9 \mathrm{~cm}$ larg. na região mediana, face externa pubérula, interna glabra, vilosa na região de inserção dos estames; anteras bitecas; ovário glabro. Cápsula elíptica, verde quando jovem, castanha quando madura, 5,0-7,0 cm compr., 3,2-3,9 cm larg., glabra, margem plana.

Material examinado: MINAS GERAIS: Grão-Mogol, Trilha da Tropa, col. $R$. Mello-Silva et al., CFCR 11421, 03.XI.1987, fr. (MO, SPF); idem, Fazenda Boa Vista, col. R. Mello-Silva et al., CFCR 10158, 06.IX.1986, fl. fr. (K, SPF); idem, estrada para o rio Ventania, col. M.T.V.A. Campos et al., CFCR 13388, 05.IX.1990, fl. (MO, SPF).

Segundo Gentry (1992), J. puberula está amplamente distribuída em florestas, desde Missiones, Argentina e Rio Grande do Sul até Bahia, Pernambuco e costa do Ceará, ocorrendo em florestas ombrófilas, florestas mesófilas semidecíduas e cerradão. Na Cadeia do Espinhaço foi coletada em mata montana, com flores em setembro e frutos em setembro e novembro.

Coleções de J. puberula provenientes de outras localidades apresentam folíolos mais pubescentes que os do Espinhaço, demonstrando ser este um caráter variável e portanto sem valor taxonômico, apesar de ter sido usado por Gentry (1992) como caráter principal na distinção entre esta espécie e J. caroba. J. caroba e $J$. puberula diferindo basicamente pelos caracteres apresentados na chave aqui proposta.

\subsection{Jacaranda pulcherrima Morawetz, PI. Syst. Evol. 132: 337. 1979.}

Arvoreta ca. 1,5 m alt.; ramos tomentosos, com entrenós longos. Folhas bipinadas, com 15-19 folíolos de $1^{\sharp}$ ordem, raque estreitamente alada; folíolos de $2^{\sharp}$ ordem coriáceos, elípticos ou oblongos, planos, 2,0-3,4 cm compr., 0,7-1,4 cm larg., sésseis ou subsésseis, ápice agudo, base atenuada, discolores, face abaxial densamente pubescente, principalmente na região das nervuras, adaxial com esparsos tricomas simples, venação pouco evidente, margem conspicuamente denteada, fortemente revoluta. Flores não vistas. Cápsula elíptica, 4,4-6,0 cm compr., 2,9-3,3 cm larg., glabra, margem plana a suavemente ondulada. 
Material examinado: MINAS GERAIS: Santa Barbára, Serra do Caraça, col. Mello Barreto 2026, 15.IX.1933, fr. (R).

Segundo Gentry (1992), J. pulcherrima é endêmica das terras altas do sudeste de Minas Gerais e morros do Rio de Janeiro e São Paulo, onde é localmente comum em vales úmidos, na transição entre cerrado e campo de altitude, entre 700-1500 m s.m. $\mathrm{Na}$ Cadeia do Espinhaço foi coletada entre rochas, com frutos em abril.

\subsection{Jacaranda caroba (Vell.) DC., Prod. 9: 232. 1845.}

Jacaranda oxyphylla Cham., Linnaea, 7: 546. 1832, syn. nov.

Figs. 3 A-K

Tipos examinados: Bignonia caroba Vellozo, Barbacena, col. Pohl 223, fl (neótipo F); Jacaranda oxyphylla Cham., Brasil, col. Sellow s.n. (lectótipo B; isótipos K, US).

Arbusto ou subarbusto, 0,8-2,5 m alt; ramos glabros, com entrenós longos. Folhas bipinadas, com 7-17 folíolos de $1^{\mathrm{a}}$ ordem, raque não alada ou estreitamente alada; folíolos de $2^{\mathrm{a}}$ ordem cartáceos, elípticos ou estreitamente elípticos, obovais ou oblanceolados, às vezes rombóides, planos, 1,2-5,0 cm compr., 0,3-1,5 cm larg., sésseis a subsésseis, ápice agudo ou acuminado, raramente arredondado ou suavemente apiculado, base cuneada ou atenuada, concolores, face abaxial glabra ou pubérula, adaxial glabra, venação broquidódroma, margem inteira, não revoluta. Inflorescência tirsóide, terminal ou axilar. Cálice vináceo, cartáceo, curtamente lobado, 0,9-1,4 cm compr., glabro ou pubérulo; corola arroxeada ou lilás, tubo 3,0-6,1 cm compr., 0,7-2,2 $\mathrm{cm}$ larg. na região mediana, face externa com tricomas glandulares concentrados principalmente na região basal, interna glabra, com esparsos tricomas glandulares na região de inserção dos estames; anteras bitecas; ovário glabro. Cápsula elíptica ou obovada, verde quando jovem, castanha quando madura, $(2,8) 3,3-6,8 \mathrm{~cm}$ compr., 1,5 $3,5 \mathrm{~cm}$ larg., glabra ou pubérula, com a margem plana ou suavemente ondulada.

Material examinado: BAHIA: Piatã, estrada Inúbia-Piatã, descida da Serra do Atalho para Inúbia, col. W. Ganev 916, 20.III.1992, fl. (K, SPF). MINAS GERAIS: Grão-Mogol, nascente do córrego das Taiobeiras, col. I. Cordeiro \& R. Mello-Silva, CFCR 10027, 02.IX.1986, fl. (K, MBM, MO, SPF); idem, córrego das Mortes, col. T.B. Cavalcanti et al., CFCR 8335, 03.IX.1985, fl. (SPF); idem, subida para o Morro Papo da Ema, col. M.T.V.A. Campos et al., CFCR 13474, 06.IX.1990, fl. fr. (MO, SPF); Virgem da Lapa, col. G. Martinelli et al. 11158, 19.VII.1985, fl. (BHCB); Itacambira, col. B. Stannard et al., CFCR 6535, 29.XI.1984, fl. (F, K, MBM, MO, SPF); idem, col. F.Rivadavia Lopes 321, 17.XII.94, fl. (SPF); Serra do Cabral, Joaquim Felício, col. R. Mello-Silva et al., CFCR 8057, 31.VIII.1985, fl. (F, MBM, MO, SPF); idem, Buenópolis, col. R.M. Harley 24957 et al., 13.X.1988, fl. (K, SPF); Couto Magalhães, col. R.M. Harley et al., CFCR 4631, 17.VII.1984, fl. (K, MBM, SPF); Diamantina, col. Mello Barreto 9336, 02.XII.1937, fr. (BHMH); idem, caminho a Conselheiro Mata, col. M.M. Arbo et al. 4415, 18.V.1990, fr. (CTES, MO, SPF); idem, $\mathrm{km} 450$ da estrada entre Presidente Juscelino e Gouveia, col. T.S.M. Grandi et al. 2258, 09.I.1987, fl. (BHCB); Santana do Riacho, Serra do Cipó, descida da Serra das Bandeirinhas, col. A.M. Giulietti et al., CFSC 12620, 28.VII.1991, fl. fr. (SPF); 
idem, rodovia Belo Horizonte-Conceição do Mato Dentro, km 105, col. J.D. de Oliveira \& G.N. Esteves, CFSC 8590, 01.VIII.1982, fl. (SPF); idem, km 105, col. J.D.P. de Oliveira \& G.L. Esteves, CFSC 8619, 01.VIII.1982, fl. (SPF, UEC); idem, $\mathrm{km}$ 106, col. S.A.P. Godoy, N.S. Chukr \& P.U. Ávila, CFSC 9848, 26.VII.1986, fl. (MO, SPF); idem, km 107, caminho para a Usina Dr. Pacífico Mascarenhas, col. E. Forero et al., CFSC 8857, 07.IX.1980, fl. (SP, SPF); idem, estrada da Usina, col. D.C. Zappi, CFSC 9342, 20.VII.1985, fl. (MO, SPF, UEC); idem, estrada da Usina, col. A.M. Giulietti et al., CFSC 5667, 16.VIII.1979, fl. (SP); idem, estrada da Usina, ca. 3$4 \mathrm{~km}$ antes da ponte sobre o rio Capivara, col. D.C. Zappi, R. Mello-Silva \& J.R. Pirani, CFSC 10294, 21.VII.1987, fl. (SPF); idem, 4 km após o Chapéu de Sol, col. M.Lucca 28, 13.IX.1992, fl. (BHCB); idem, km 111, A.B. Joly, J. Semir \& Y. Ugadim, CFSC 60, 06.VII.1970, fl. fr. (SP); idem, km 112, col. M. Sakane, CFSC 659, 25.X.1977, fl. e fr. (SP); idem, km 113, col. A.B. Joly et al., CFSC 1533, 15.IV.1972, fl. (SP); idem, km 113, J. Semir \& M. Sazima, CFSC 3418, 06.IX.1972, fl. fr. (SP); idem, km 114, col. V.C. Souza, C.M. Sakuragui \& L.G. Lohmann, CFSC 13116, 02.V.1993, fl. (SPF); idem, km 128, Alto do Palácio, col. L.G. Lohmann et al. 64, 27.I.1996, fr. (SPF); idem, em frente ao Alto do Palácio,col. M. Lucca 29, 13.IX.1992, fl. (BHCB); idem, col. L.G. Lohmann et al. 52, 4.IX.1995, fl. (SPF); idem, col. E.P. Heringer 2686, 15.I.1951, fl. (RB); idem, col. A.P. Duarte 6431, 26.X.1961, fl. (RB); idem, col. A.J. Lombardi \& F.R.N. Toledo 257, 24.V.1993, fr. (BHCB); idem, col. J.A. Lombardi \& F.R.N. Toledo 395, 22.VII.1993, fl. (BHCB); idem, col. J.A. Lombardi \& F.R.N. Toledo s.n., 20.VIII.1993, fl. (BHCB 22221); Sete Lagoas, col. L. Rennó s.n., VIII.1957, fl. (BHCB 141); Lagoa Santa, col. J. Augusto s.n., 3.VI.1970, fl. (BHCB 2404); Santa Luzia, col. Mello Barreto 1858, 28.VIII.1933, fl. (BHMH); Serra do Taquaril, col. Mello Barreto 1856, 19.V.1933, fl. (BHMH); Morro do Chapéu, Nova Lima, col. T.S.M. Grandi et al. s.n., 25.VII.1982, fl. (BHCB 4209); Brumadinho, Serra da Calçada, col. L.A. Martens s.n., 28.X.1989, fl., (SPF 87177); idem, Serra da Calçada, col. L.A. Martens s.n., 10.XII.1988, fl. fr., (SPF 87175); idem, Serra do Rola Moça, col. El Borba 48, 19.IX.1993, fl. (BHCB); idem, Retiro das Pedras, col. M.H.L. Arndt et al., 16.III.1990, fl. (BHCB 18632); idem, col. J.A. Lombardi \& J.R. Stehmann 467, 02.XI.1993, fl., fr. (BHCB); idem, col. J.R. Stehmann \& G. Brandão 1409, 14.III.1994, fr. (BHCB); Serra da Moeda, col. T.S.M. Grandi et al. 2726, 04.X.1989, fl. (BHCB); idem, estrada Vicinal, km 561, col. J.L.M. Wykrota \& J.M.P. Costa 9, 12.IX.1987, fl. (BHCB); Pico do Itabirito, col. W.A. Teixeira s.n., 11.IX.1993, fl. (BHCB 24251); Serra do Ouro Branco, col. C.M. Braccini s.n., 02.X.1988, fl. (BHBC 13969).

Jacaranda oxyphylla foi primeiramentemente tratada por Bureau \& Schumann (1897) como uma variedade de J. caroba com folíolos mais estreitos. Mais recentemente, na revisão de Gentry \& Morawetz (1992), foi levada à categoria de espécie com base no tamanho dos folíolos e habitat, J.caroba com folíolos maiores restrita ao cerrado, e $J$. oxyphylla dos campos limpos e margens de florestas adjacentes. Na Cadeia do Espinhaço, no entanto, formas que seriam atribuídas a $J$. caroba foram comumente ncontradas em cerrado e campo rupestre, em MG e em campo de encosta 


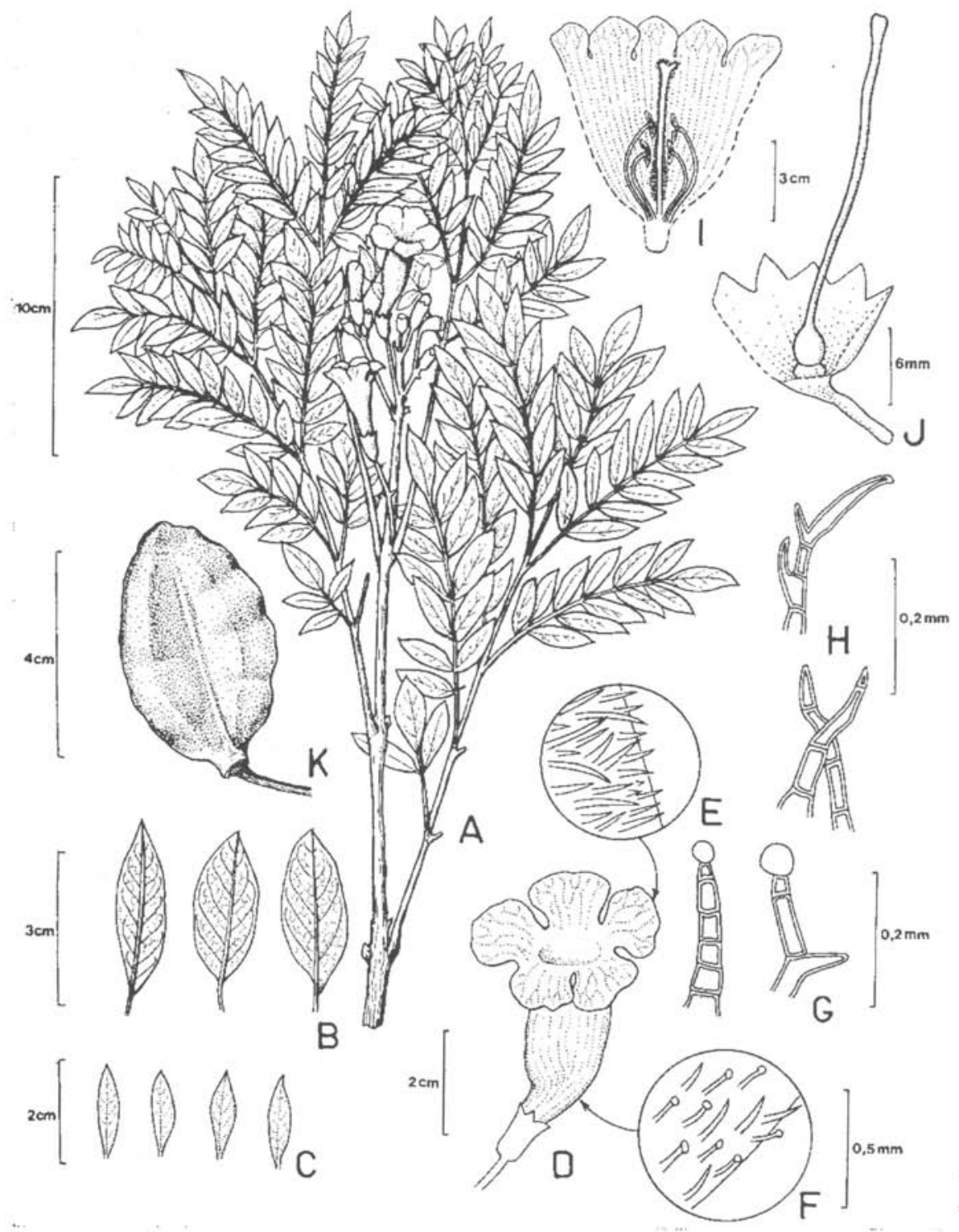

Figura 3. A-K: Jacaranda caroba (Vell.) DC. A: Ramo (CFSC 8590); B: Folíolos (CFSC 1533); C: Folíolos (CFSC 2857); D: Aspecto geral da flor (CFSC 12620); E: Detalhe do indumento da face externa dos lobos da corola; F: Detalhe do indumento da base externa da corola; G: Tricomas glandulares da base externa da corola; H: Tricomas simples da face externa dos lobos da corola; I: Corola aberta (CFSC 12620); J: Cálice aberto e ovário (CFSC 12620); K: Fruto (CFSC 659). 
com carrasco na Bahia, e também m matas ripárias. Formas compatíveis com $J$. oxyphylla foram encontradas em cerrados nesta mesma região. Este fato, aliado à constatação de que os folíolos apresentam dimensões extremamente variáveis forneceram evidências para tratá-las como uma mesma espécie.

Segundo Gentry (1992), J. caroba ocorreria nos cerrados brasileiros, nos estados de São Paulo, Minas Gerais, Goiás e Distrito Federal entre 600-1600 m. s.m. Com esta nova acepção a distribuição da espécie estende-se para o Paraná e Bahia, crescendo em campos limpos, florestas de galeria e cerradões. Na Cadeia do Espinhaço, foi freqüentemente coletada em cerrados de encosta e em campos rupestres somente com flores em janeiro, com flores e frutos de março a novembro e apenas com frutos em dezembro.

2.6. Jacaranda racemosa Cham., Linnaea, 7: 547. 1832.

Figs. 4 A-H

Subarbusto $20-50 \mathrm{~cm}$ alt., apresentando xilopódio; ramos glabros. Folhas pinadas, em roseta basal, dispostas em ramos com entrenós curtos, com 19-29 folíolos, raque não alada; folíolos cartáceos, oblanceolados a obovais, planos, 1,1-3,6 cm compr., 0,2-0,8 cm larg., sésseis ou subsésseis, ápice acuminado, agudo ou arredondado, base cuneada, concolores, glabros, venação broquidódroma, margem inteira, não revoluta. Inflorescência botrióide, terminal. Cálice vináceo, coriáceo, ligeiramente partido, 0,8-0,4 cm compr., 0,3-0,5 cm larg., glabro; corola rosa ou purpura, tubo 2,2$3,8 \mathrm{~cm}$ compr., $0,8-1,8 \mathrm{~cm}$ larg. na região mediana, face externa pubérula, interna glabra, exceto na região de inserção dos estames; anteras bitecas; ovário glabro. Cápsula obovada, vinácea a arroxeada, 2,8-3,4 cm compr., 1,6-1,8 cm larg., glabra, com a margem plana ou suavemente ondulada.

Material examinado: MINAS GERAIS: entre Diamantina e Mendanha, col. I. Cordeiro et al., CFCR 569, 12.VII.1980, fl. fr. (SPF); Diamantina, col. Mello Barreto 9376, 03.XI.1937, fl. (R); idem, col. Mello Barreto 9643, 09.XI.1937, fl. fr., (R); idem, col. T.B. Cavalcanti et al., CFCR 8599, 22.XI.1985, fl. (F, K, MBM, MO, NY, SPF); idem, col. E.M. Isejima et al., CFCR 5562, 13.X.1984, fl. (SPF); idem, col. R.M. Harley et al. 25440, 30.X.1988, fl. (K, SPF); idem, col. A. Salatino et al., CFCR 11908, 11.XII.1987, fl. (SPF); idem, col. A.M. Giulietti et al., CFCR 2256, 29.X.1981, fl. (F, MICH, SPF); idem, col. M.M.N. Braga \& A.L.F. Chaves 463, 03.XII.1991, fl. (BHCB); idem, col. M.M.N. Braga, 10.I.1987, fl. (BHCB 10659); idem, col. Mello Barreto 9376, 3.XI.1937, fl. (BHMH); entre Diamantina e Extração, col. N.S. Ávila, CFCR 15427, 11.I.1995, fl. (SPF); Boa Vista, caminho entre Diamantina e Extração, col. Mello Barreto 9643, 9.XI.1937, fl. (BHMH); entre Diamantina e Conselheiro Mata, col. T.S.M. Grandi et al. 2323, 10.I.1987, fl. (BHCB); Santana do Riacho, rodovia Belo Horizonte-Conceição do Mato Dentro, km 3, Alto Congonhas, col. M.M. Arbo et al. 4739, 09.II.1991, fl. (SPF); idem, km 109, col. E. Forero et al., CFSC 8628, 6.IX.1980, fl. (SP, SPF); idem, km 112, col. anônimo, CFSC 652, 25.X.1977, fl. (SP); idem, km 114, col. J. Semir \& M. Sazima, CFSC 671, 7.II.1972, fl. (SP); idem, km 114, col. J. Semir \& M. Sazima, CFSC 3356, 4.IX.1972, fl. (SP); idem, km 114, 
col. A.B. Joly et al., CFSC 4484, 18.X.1973, fl. (SP); idem, km 114, col. A.B. Joly \& J. Semir, CFSC 3670, 4.XI.1972, fl. fr. (SP); idem, km 119, Santa Luzia, col. Mello Barreto 2027, 23.VIII. 1933, fl. (BHMH); idem, km 120, col. H. Longhi-Wagner et al., CFCR 5943, 14.XI.1984, fl. (SPF); idem, km 128, Retiro da Fazenda Palácio, cachoeira do Capivara, col. D.C. Zappi, A. Salatino \& M.L.F. Salatino, CFSC 10031, 26.II.1987, fl. (SPF); idem, km 128, col. A.B. Joly et al., CFSC 3690, 4.XI.1972, fl. (SP); idem, km 136, col. A. Sampaio 6685, 2.II.1934, fr. (BHMH); idem, km 141, col. Mello Barreto 5120, 30.X.1936, fl. (R); idem, col. F. de Barros s.n., 06.IX.1980, fl. (SP 232328); idem, km 141, col. Mello Barreto 5126, 30.X.1936, fl. (BHMH); idem, Cachoeira da Capivara, col. L.G. Lohmann et al. 65, 27.I.1996, fl. fr. (SPF); idem, Fazenda Palácio, col. Cuezzo 3498, 22.XII.1948, fl. (R); idem, Fazenda Palácio, col. T.A. Anacleto et al. s.n., 18.XI.1989, fr. (BHCB 16545); idem, col. L.B. Smith 1560, X.1953, fl. (R); idem, col. J.R. Stehlmann et al. s.n., 20.X.1990, fl. (BHCB 18879); idem, col. A. Giani s.n., 24.XI.1984, fl. (BHCB 6034).

Segundo Gentry (1992), J. racemosa é endêmica da área de campo rupestre aberto, crescendo sobre solo arenoso, sendo encontrada na Cadeia do Espinhaço em Minas Gerais. Os materiais examinados provêm todos da Serra do Cipó e do Planalto de Diamantina, coletados em campo rupestre, cerrado e brejo, entre rochas e em solo arenoso. Flores foram encontradas de agosto a fevereiro. Frutos, apenas em feverreiro, julho e em novembro.

\subsection{Jacaranda paucifoliolata Mart ex DC., Prodr. 9: 230.1845.}

Figs. 4 I-P

Subarbusto 0,2-1,0 $\mathrm{m}$ alt.; ramos pubérulos. Folhas pinadas, 5-9 folioladas, dispostas em ramos com entrenós longos, raque não alada; folíolos coriáceos, obovais a oblongo-elípticos, planos, 1,3-7,2 cm compr., 0,7-4,4 cm larg., sésseis ou curtamente peciolados, ápice arredondado ou agudo, às vezes apiculado, base cuneada, discolores, face abaxial pubescente e esbranquiçada, adaxial glabra a pubérula, venação broquidódroma, margem inteira ou com dentes esparsos, não revoluta. Inflorescência tirsóide, terminal. Cálice verde-arroxeado, cartáceo, curtamente denteado, 0,4-0,7 cm compr., 0,3-0,5 cm larg., pubérulo e esbranquiçado; corola arroxeada a lilás escuro, tubo 3,4-4,2 cm compr., 0,8-1,6 cm larg. na região mediana, face externa com esparsos tricomas simples e glandulares, principalmente na base, interna glabra, vilosa na região de inserção dos estames; anteras bitecas; ovário glabro. Cápsula orbicular, castanha a marrom-esverdeada, glabra, com a margem plana a suavemente ondulada.

Material examinado: MINAS GERAIS: Grão-Mogol, estrada para o rio Ventania, col. G.L. Esteves et al., CFCR 13364, 05.IX.1990, fr. (MO, SPF); idem, Vale do rio Itacambiruçu, col. A. Freire-Fierros et al., CFCR 12355, 10.XII.1989, fl. (SPF); estrada de Grão-Mogol para Montes Claros, col. L. Rossi et al., CFCR 1015, 16.IV.1981, fl. (SPF); Cristália, Fazenda Curral Velho, col. M.G. Carvalho \& S.T. Silva 151, 25.IV.1991, fl. (BHCB); Serra do Cabral, col. W.W. Thomas et al. s.n., 13.II.1988, (SPF, NY 5944); estrada entre Couto de Magalhães e Diamantina, km 19, col. G. Martinelli \& B.E. Leuenberger 9214, 03.IV.1983, fl. (RB); Diamantina, col. A. 
Lutz 1535, 17.XI.1919, fl. (R); idem, caminho da cascatinha, col. M.M.N. Braga s.n., 10.I.1987, fl. (BHCB 10630); idem, Barro Preto, col. Mendes Magalhães 1928, 30.IV.1935, fl. fr. (BHMH); caminho a Gouveia, col. M.M. Arbo et al. 5027, 13.II.1991, fl. (CTES, SPF); Congonhas do Norte, col. A. Furlan, N. Hensold \& M.C.E. Amaral, CFSC 11944, 20.IV.1982, fl. (SPF); Serra do Cipó, Reserva do IBAMA, col. R. Simão-Bianchini, CFSC 11698, 27.I.1990, fl. (SP); idem, caminho da Base do IBAMA para o Capão dos Palmitos, col. J.R. Pirani et al., CFSC 11944, 25.III.1991, fl. fr. (SPF); idem, estrada para o Capão dos Palmitos, col. N. Roque \& J.F. Coffani-Nunes, CFSC 13156, 08.VI.1993, fl. (SPF); idem, rodovia Lagoa SantaConceição do Mato Dentro, km 106, col. G. Martinelli et al. 11333, 21.I.1986, fl. (RB); idem, km 110, col. M. Sazima \& J. Semir, CFSC 3825, 16.II.1973, fl. (SP); idem, km 110, col. C. Kameyama \& D.C. Zappi, CFSC 9644, 24.III.1986, fl. fr., (SPF); idem, km 112, col. A.B. Joly et al., CFSC 1000, 5.III.1972, fl. (SP); idem, km 113, col. A.B. Joly et al., CFSC 1532, 15.IV.1972, fl. (SP); idem, km 113, col. A.B. Joly, et al., CFSC 1495 e CFSC 1505, 15.IV.1972, fl. (SP); idem, km 114, col. I. Cordeiro et al., CFSC 6042, 29.III.1980, fl. (SP); idem, km 114, col. A.M. Giulietti \& N. Menezes, CFSC 3967, 26.II.1973, fl. (SPF); idem, km 129, col. H. Duarte 2527, 17.IV.1950, fl. (RB); idem, km 136, col. I. Cordeiro et al., CFSC 6068, 30.III.1980, fl. (SP); idem, Chapéu de Sol, col. J. Vidal V-4, XII.1957, fl. (R); idem, col. A.P. Duarte 8094, 19.VI.1964, fl. fr. (RB); idem, km 2 da estrada da Usina, col. A. B. Joly et al., CFSC 1204 e CFSC 1184, 5.III.1972, fl. (SP); estrada da Usina, col. J. Semir et al., CFSC 9622, 22.II.1986, fl. (SPF); idem, Posto Palácio, col. J. Vidal II-6068, XII.1953, fl. (R); abaixo da Casa de Pedra e próximo ao córrego Gavião, col. M.Lucca 30, 14.III.1993, fl. (BHCB); Vale do córrego da Mãe d'Água, col. D.C. Zappi \& J.R. Pirani, CFSC 10312, 21.VII.1987, fr. (SP); idem, km 662, col. M. Sakane, CFSC 662, 25.X.1977, fl. (SP); 10-20 km NE de Cardeal Mota, col. M.M. Arbo et al., CFSC 4128, 15.V.1990, fl. (SPF); idem col. R. Simão et al., CFSC 11048, 11.I.1988, fl. fr. (SPF); idem, col. A.P. Duarte 7804, 27.IV.1963, fl. fr. (RB); idem, col. E.P. Heringer 2711, 14.I.1951, fl. (RB); idem, col. E.P. Heringer \& Castellanos 22040, 03.III.1958, fl. (R); São José da Serra, col. J.A. Lombardi \& F.R.N. Toledo 494, 14.XII.1993, fl. (BHCB); entre São José da Almeida e Santa Luzia, col. Mello Barreiro 816, 2.II.1934, fl. (BHMH); Santa Luzia, col. Mello Barreto \& Brade 1265, 15.IV.1935, fl. (BHMH); caminho a Santana do Riacho, col. M.M. Arbo et al. 4901, 11.II.1991 (CTES, SPF); Santana do Riacho, col. J.A. Lombardi \& F.R.N. Toledo 262, 24.V.1993, fr. (BHCB); idem, estrada para Lapinha, $1000 \mathrm{~m}$ alt., col. J.S. Silva et al., CFSC 1931, fl. (SP); idem, Cascalheira, col. M.A. Lopes \& P.M. Andrade s.n., 25.II.1985, fl. (BHCB 8742); Serra do Taquaril, col. Mello Barreto 798, 3.XII.1932, fl. (BHMH).

Jacaranda paucifoliolata, segundo Gentry (1992), é conhecida somente da Cadeia do Espinhaço em Minas Gerais e da Serra dos Cristais e Serra Dourada, em Goiás, ocorrendo em cerrado arbustivo e campo cerrado. Na Cadeia do Espinhaço é freqüente, ocorrendo em campo rupestre e cerrado denso, em solo areno-pedregoso. Flores foram encontradas de janeiro a junho, em outubro e em dezembro. Frutos de março a julho e em setembro. 


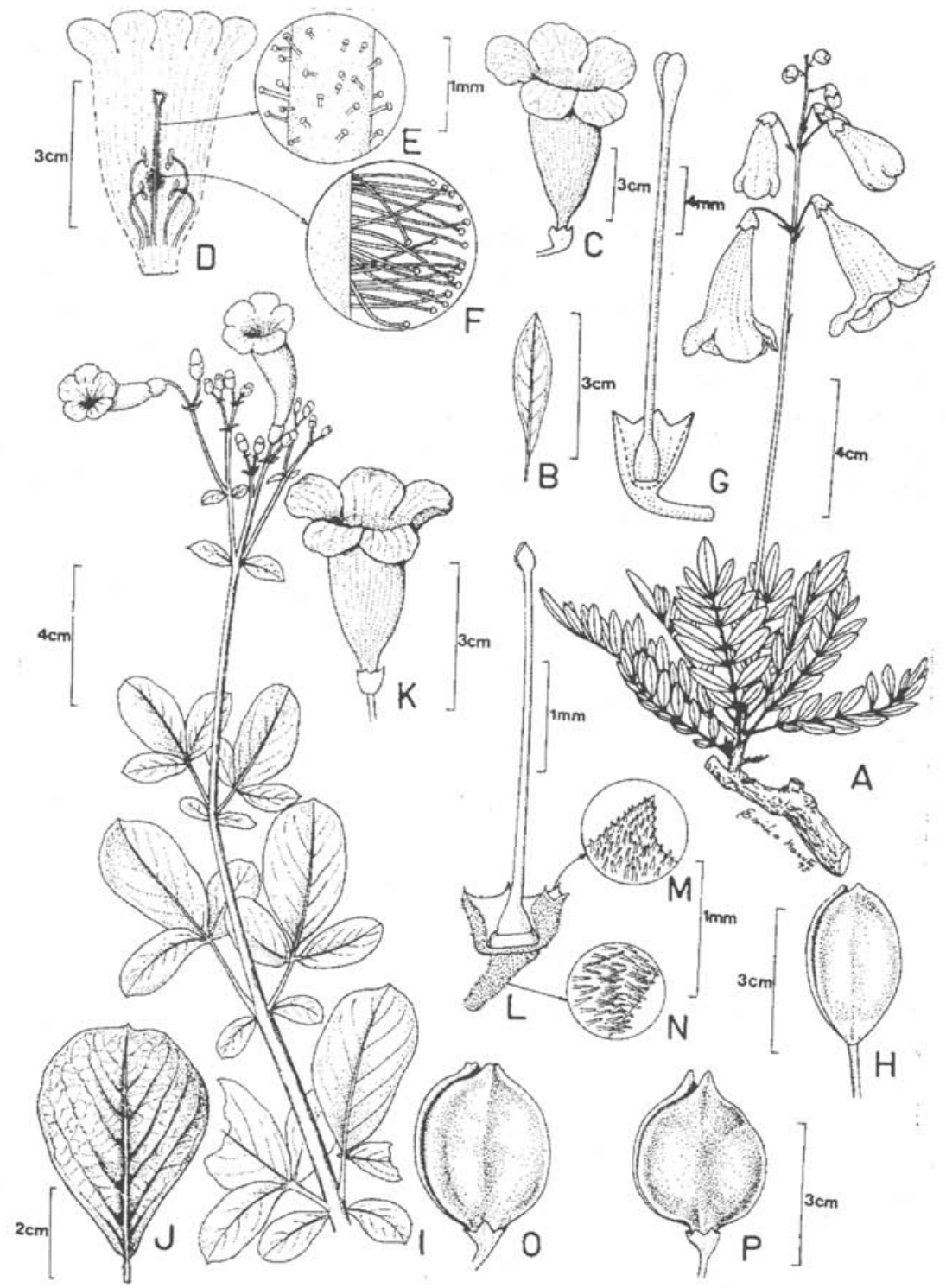

Figura 4. A-H: Jacaranda racemosa Cham. A: Hábito (CFSC 4739); B: Folíolo (CFSC 3670); C: Aspecto geral da flor (CFSC 4739); D: Corola aberta (CFSC 10031); E: Detalhe dos tricomas da regiâo apical do estaminódio; F: Detalhe dos tricomas da região mediana do estaminódio; G: Cálice aberto mostrando o ovário (CFSC 10031); H: Fruto (CFSC 3670). I-P: Jacaranda paucifoliolata Mart. ex DC. I: Hábito (CFSC 1505); J: Folíolo (CFSC 1505); K: Aspecto geral da flor (CFSC 11048); L: Cálice aberto mostrando ovário; M: Detalhe dos tricomas do lobo do cálice; N: Detalhe dos tricomas do pedicelo; O e P: Frutos (CFSC 10312). 
2.8. Jacaranda irwinii Gentry, Ann. Missouri Bot. Gard. 61: 880. 1974.

Figs. 5 A-F

Arbusto delgado ou arvoreta, 1,3-3,0 m alt.; ramos pubescentes, com entrenós longos. Folhas pinadas, 9-15 folioladas, raque não alada; folíolos coriáceos, obovais a oblongo-elípticos, planos, 3,2-8,5 cm compr., 1,4-4,7 cm larg., sésseis ou subsésseis, ápice arredondado, agudo, ligeiramente obcordado, ou mucronado, base aguda, levemente atenuada, discolores, indumento variável, face abaxial geralmente glabra ou pubérula, adaxial glabra a fortemente pubescente, venação broquidódroma, margem inteira, revoluta. Inflorescência tirsóide, terminal ou axilar. Cálice vináceo, coriáceo, partido até a metade, 0,4-0,7 cm compr., 0,4-0,6 cm larg., pubérulo; corola lilás arroxeada externamente, tubo ventralmente alvo na face interna, tubo $2,7-4,2 \mathrm{~cm}$ compr., 1,0-1,3 cm larg. na região mediana, face externa com tricomas simples, distribuídos principalmente pela base, interna glabra, vilosa na região de inserção dos estames e lobos; anteras bitecas; ovário glabro. Cápsula elíptica, avermelhada, 2,4-5,8 cm compr., 1,7-3,3 cm larg., glabra, com a margem plana a suavemente ondulada.

Material examinado: BAHIA: Jacobina, Morro do Cruzeiro, col. J.R. Pirani et al., CFCR 7525, 23.XII.1984, fl. fr. (F, K, SPF); Seabra, col. J.R. Pirani et al. 1977, 13.II.1987, fl. (K, MO, SPF); Andaraí, col. R.M. Harley et al. 18617, 13.II.1977, fl. (SPF); Mucugê, col. A. Furlan et al., CFCR 419, 06.XII.1980, fl. (SPF); idem, col. R.M. Harley et al. 18784, 17.II.1977, fl. (K, SPF); idem, col. J.R. Pirani et al., CFCR 1612, 21.VII.1981, fl. fr. (K, MO, SPF); idem, col. G.P. Lewis et al., CFCR 7044, 17.XII.1984, fl. (K, MO, SPF); idem, Alto do Cruzeiro, ao lado da cidade, col. F. Rivadavia Lopes \& E. da Silva Rocha 464, 22.VII.95, fl. (SPF); Piatã, quebrada da Serra do Atalho, col. R.M. Harley et al., H 50395, 26.XII.1991, fl. (CEPEC, HUEFS, $\mathrm{K}, \mathrm{SPF})$; Abaíra, estrada entre Jambeiro e Belo Horizonte, col. W. Ganev 211, 2.V.1992, fl. (K, SPF); Jussiape, col. R.M. Harley et al. 24339, 16.VII.1981, fl. (K, SPF); idem, Riacho da Taquara, col. B. Stannard \& T. Silva, H 50850, 28.I.1992, fl. fr. (K, SPF); Rio de Contas, Pico das Almas, col. R.M. Harley et al. 24446, 20.II.1987, fl. (K, SPF); estrada entre Capão da Volta e Barra da Estiva, col. A.M. Giulietti et al., CFCR 1348, 19.VII.1981, fr. (MO, SPF).

Segundo Gentry (1992), J.irwinii é endêmica da Serra do Sincorá e Serra do Tombador no centro-oeste da Bahia, ocorrendo principalmente em campo rupestre entre 800-1300 m. Com a coleção CFCR 7525 amplia-se a distribuição conhecida até a Serra de Jacobina, mais ao norte da Bahia. Ocorre em carrascal, em encostas íngremes, em mata de cipó pertubada, em campo rupestre (crescendo em solo arenopedregoso) e em campo arenoso. Foi encontrada florescendo em fevereiro, julho e dezembro e frutificando em julho e dezembro.

\section{Tabebuia Gomes}

Árvores, arvoretas ou arbustos. Folhas digitadas 3-7(-9)-folioladas ou raramente simples, geralmente decíduas, raque nunca alada. Inflorescência tirsóide ou botrióide, terminal ou axilar. Cálice campanulado, geralmente 5-denteado, às vezes bialado, lobos agudos ou arredondados, coriáceo, com pilosidade variável; corola amarela, 


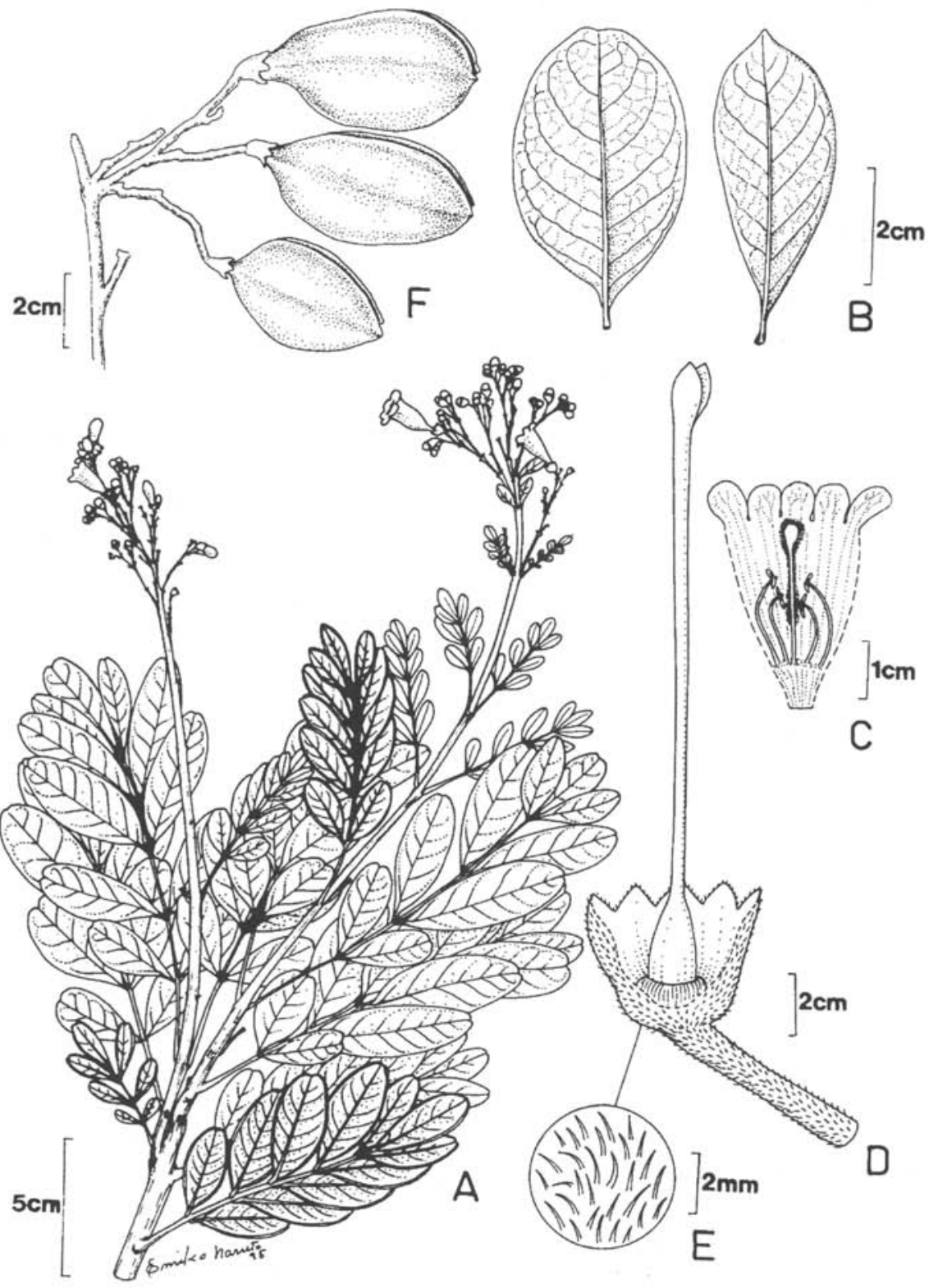

Figura 5. Jacaranda irwinii A. Gentry. A: Hábito (Harley 24339); B: Folíolos (Pirani 1977 e CFCR 419); C: Corola aberta (CFCR 419); D: Cálice aberto mostrando ovário (CFCR 419); E: Detalhe dos tricomas simples da face externa do cálice; F: Frutos (CFCR1348). 
raramente branca ou lilás, tubular-campanulada, membranácea, glabra ou pubérula; anteras bitecas, glabras, estaminódio reduzido, glabro ou piloso na região de inserção dos estames; ovário oblongo, geralmente glabro ou lepidoto, às vezes com pilosidade variável, óvulos 2-8-seriados em cada lóculo; disco nectarífero anular. Cápsula linearcilíndrica, coriácea, lisa, geralmente pubescente, margem plana. Sementes finas com alas membranáceas.

Gênero neotropical, com 100 espécies no tratamento de Gentry (1992). Na Cadeia do Espinhaço, foram registradas 6 espécies.

Chave para as espécies de Tabebuia do Espinhaço

1. Folíolos glabros; cálice densamente lepidoto, com glândulas esparsas .........T. aurea 1'. Folíolos pubérulos a pubescentes; cálice subglabro a pubescente, sem glândulas

2. Arbusto; cálice esparsamente pubescente a subglabro T.pumila 2'. Árvores ou arvoretas; cálice densamente pubescente ou viloso

3. Folíolos inteiros, glabrescentes na face adaxial; venação broquidódroma .T.ochracea ssp.ochracea

3'. Folíolos serreados, glabros na face adaxial; venação craspedódroma 4. Folíolos concolores; inflorescência com eixo principal alongado; corola pubérula na fauce T. bureavii 4'. Folíolos discolores; inflorescência com eixo principal curto; corola vilosa na fauce

5. Folíolos com ápice arredondado, raramente agudo, sem glândulas; inflorescência congesta, globosa, com ramos laterais contraídos; ovário glabro T. vellosoi

5'. Folíolos com ápice agudo ou acuminado, com glândulas plateliformes próximas a nervura principal; inflorescência laxa, com ramos laterais alongados; ovário finamente lepidoto T. alba

3.1. Tabebuia aurea (Manso) Benth. \& Hook. f. ex S. Moore, Trans. Linn. Soc. 2, Bot: 4: 423.1895.

Figs. 6 A-G

Árvore ou arvoreta tortuosa, 3-4 m alt.; ramos glabros. Folhas 5-folioladas; folíolos coriáceos, elípticos a oblongo-elípticos, planos, 9,0-12,6 cm compr., 5,0-7,5 $\mathrm{cm}$ larg., ápice arredondado, base arredondada a obtusa, concolores, glabros, venação broquidódroma, margem inteira, suavemente revoluta; pecíolos não vistos. Inflorescência tirsóide, séssil, terminal. Cálice castanho-esverdeado, irregularmente partido, 1,2-1,4 cm compr., 0,6-0,9 cm larg., densamente lepidoto, com glândulas esparsas; corola amarelo-ouro, tubo 5,0-8,0 cm compr., 1,5-2,3 cm larg. na região mediana, glabra em ambas as faces, pubescente na região de inserção dos estames; ovário densamente lepidoto. Frutos e sementes não vistos.

Material examinado: MINAS GERAIS: estrada que liga Grão-Mogol a Salinas, col. T.S.M. Grandi s.n., 26.VIII.1988, fl. (BHCB 13543); Confins, col. C.C. Reis \& 
T.S.M. Grandi s.n., 26.VIII.1988, fl. (BHCB 13438); Serra do Espinhaço, col. G. Hatschbach \& R. Kummrow 49590, 12.IX.1985, fl. (MBM, SPF); Santana do Riacho, Serra do Cipó, no caminho para a Cachoeira da Farofa, col. T.B. Cavalcanti et al., CFSC 10603, 07.IX.1987, fl. (SPF); idem, ao longo da rodovia Belo Horizonte-Conceição do Mato Dentro, col. L.G. Lohmann et al. 38, 3.IX.1995, fl. (SPF); Lagoa Santa, col. anônimo, 11.IX.1902, fl. (R 28821); idem, col. O. Williams \& V. Assis 7406, fl. (R); idem, col. C.C. Reis \& T.S.M. Grandi s.n., 12.VIII.1988, fl. (BHCB 13377).

Segundo Gentry (1992), T. aurea é característica do cerrado brasileiro, sendo também encontrada nas florestas secas da Argentina, oeste da Bolívia e savanas do sudeste do Suriname, além de ser amplamente cultivada. Na Cadeia do Espinhaço ocorre em áreas de cerrado e em campo rupestre, tendo sido encontrada com flores em agosto, setembro e em novembro. É freqüentemente referida na literatura florística brasileira como T. caraiba (Mart.) Bur., um sinônimo.

\subsection{Tabebuia pumila A.Gentry, Flora Neotropica 25(2): 244. 1992.}

Figs. 7 A-D

Arbusto até $1 \mathrm{~m}$ alt.; ramos glabros a minutamente pubérulos. Folhas 3folioladas; folíolos coriáceos, elípticos, ovais ou obovais, planos, 5,5-12,5 cm compr., 2,1-6,7 cm larg., sésseis ou com peciólulos até $0,5 \mathrm{~cm}$ compr., ápice agudo ou arredondado, base cuneada, concolores, face abaxial pubérula, adaxial pubescente na região próxima às nervuras, venação craspedódroma, margem irregularmente serreada ou crenulada, raramente inteira, não revoluta; pecíolos 0,8-1,2 cm compr., glabros. Inflorescência botrióide, congesta, com eixo principal muito curto, terminal. Cálice verde, conspicuamente partido, 0,5-0,6 cm compr., 0,4-0,6 cm larg., esparsamente pubescente, sem glândulas; corola amarelo-ouro, com estrias castanhas na porção ventral interna do tubo, 3,2-4,4 cm compr., 0,9-1,3 cm larg., glabra em ambas as faces, vilosa na região de inserção dos estames; ovário glabro. Frutos e sementes não vistos.

Material examinado: MINAS GERAIS: Grão-Mogol, Fazenda Boa Vista, col. R. Mello-Silva \& I. Cordeiro, CFCR 1014I, 06.IX.1986, fl. (MO, SPF); Jambeiro a 7 km de Grão-Mogol,col. R. Mello-Silva et al., CFCR 8474, 05.IX.1985, fl. (MO, SPF); $\mathrm{Km} 36$ da BR que leva a estrada de Montes Claros a Grão-Mogol, col. T.S.M. Grandi et al. s.n.,27.VIII.1988, fl. (BHCB 13519); Serra do Cabral, col. M.L. Kawasaki et al., CFCR 24339, 02.IX.1985, fl. (SPF); Diamantina, col. R. Mello-Silva et al. 355, 20.VIII.1990, fl. (SPF); idem, col. R. Mello-Silva, J.R. Pirani \& M. Meguro, CFCR 7973, 03.VIII.1985, fl. (SPF); idem, col. A.M. Giulietti et al., CFCR 1857, 30.VII.1981, fl. (holótipo SPF, isótipo MO).

É endêmica dos campos rupestres do Planalto de Diamantina e da Serra de GrãoMogol. Foi coletada em campo de cimeira, à beira de mata, em solo areno-pedregoso com canga de hematita e entre vegetação arbustiva com elementos de cerrado. Foi encontrada com flores em agosto e setembro.

\subsection{Tabebuia ochracea (Cham.) Standl., Field Mus. Nat. Hist., Bot. Ser. 11:176.1936.} Figs. $6 \mathrm{H}-\mathrm{N}$ 

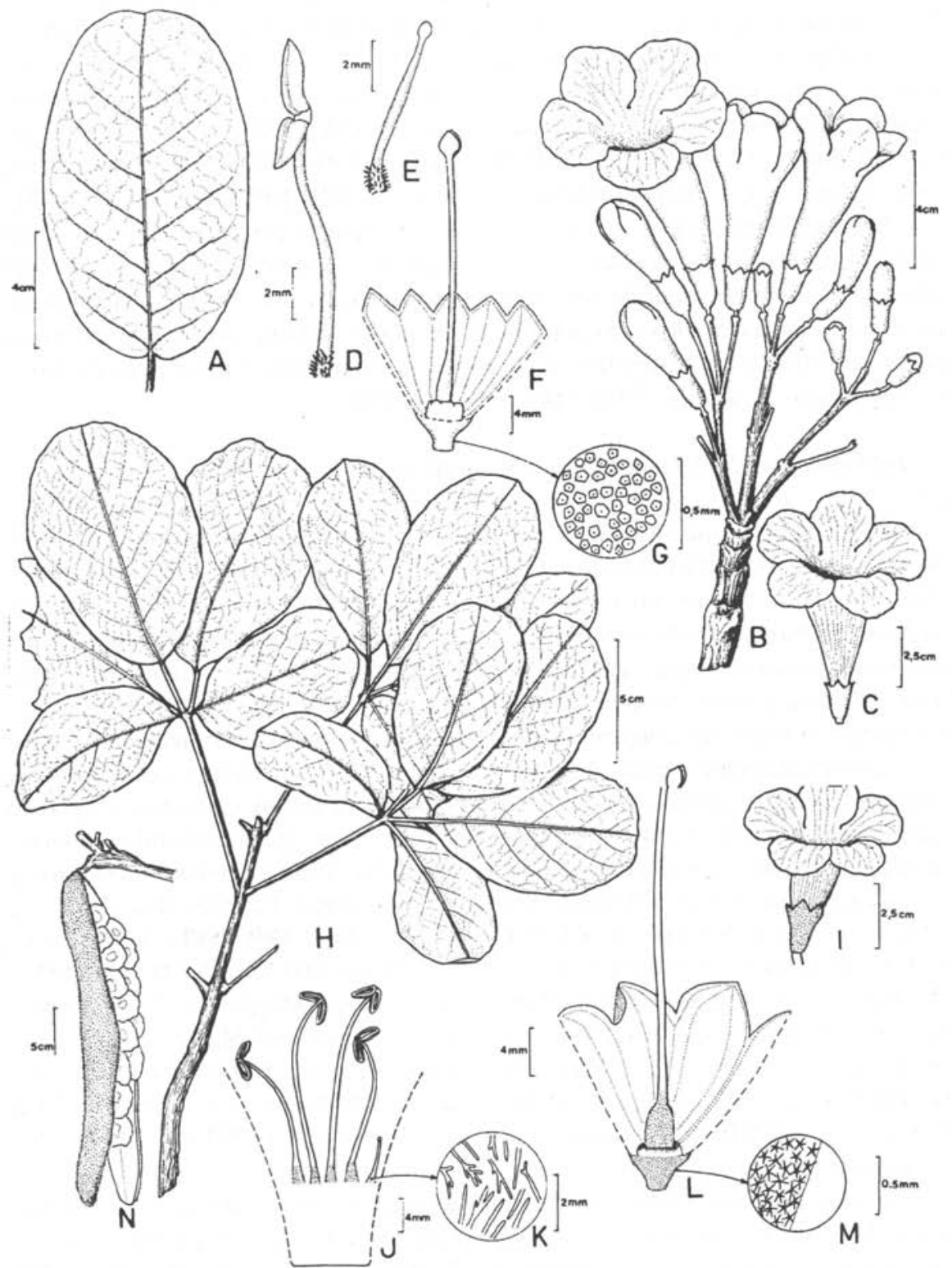

Figura 6. Tabebuia aurea (Manso) Benth. \& Hook. A: Folíolo (Hatschbach 49590); B: Inflorescência (CFSC 10603); C: Aspecto geral da flor (CFSC 10603); D: Estame (CFSC 10603); E: Estaminódio (CFSC 10603); F: Cálice aberto mostrando ovário (CFSC 10603); G: Detalhe de glândulas do cálice. H-N: Tabebuia ochracea (Cham.) Standl. H: Ramo (CFSC 11032); I: Aspecto geral da flor (CFSC 9004); J: Estames e estaminódio (CFSC 9004); K: Detalhe dos tricomas da região de inserção dos estames; L: Cálice aberto mostrando ovário (CFSC 9004); M: Tricomas do cálice; N: Fruto. 


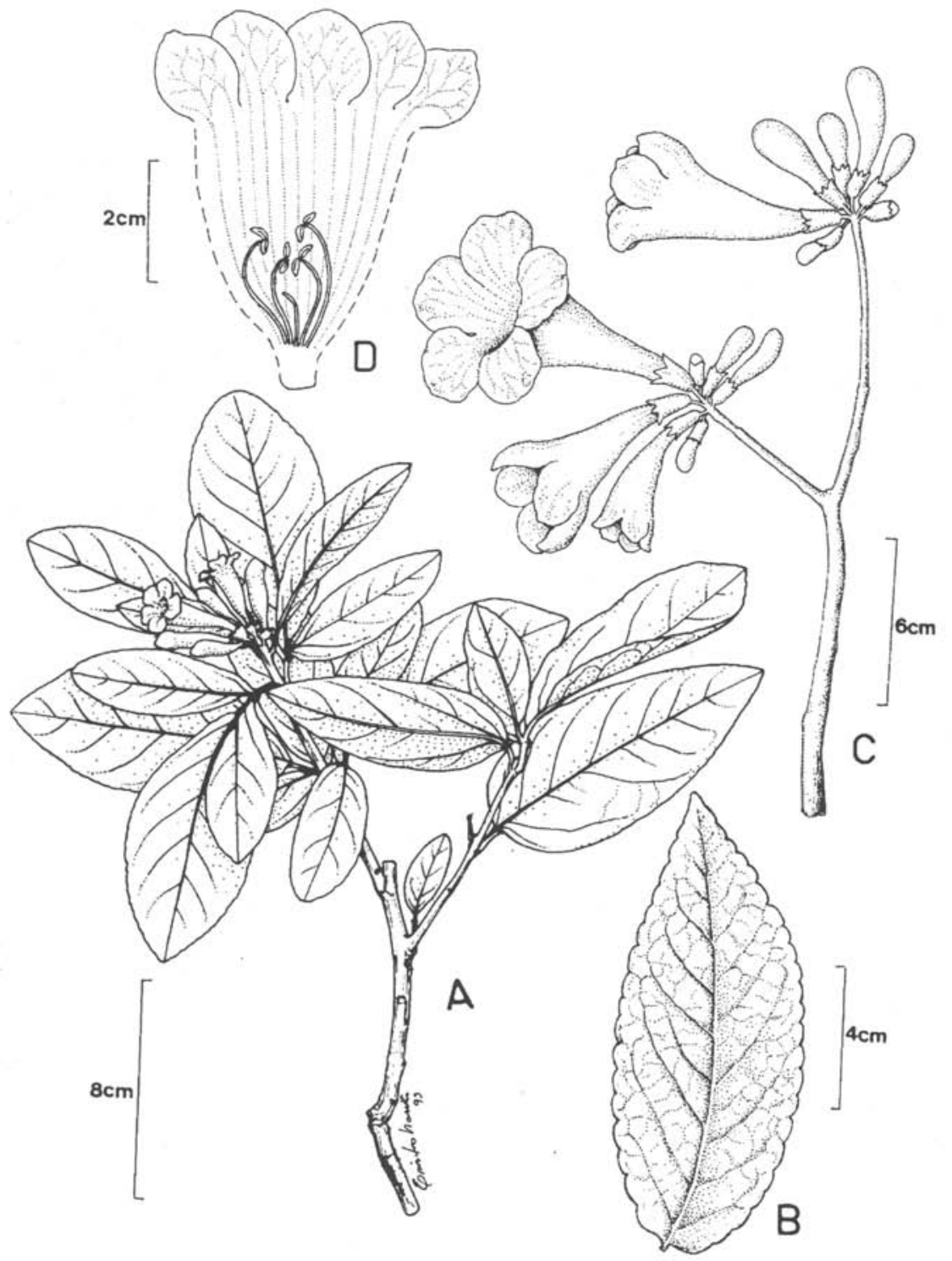

Figura 7. Tabebuia pumila A. Gentry. A: Ramo (CFCR 1857); B: Folíolo (CFCR 8474); C: Inflorescência (CFCR 1857); D: Corola aberta (CFCR 1857). 
Árvore ou arvoreta de 2,5-7,0 m alt., ou arbusto de $30-50 \mathrm{~cm}$ alt.; ramos pubescentes. Folhas 3-5-folioladas; folíolos coriáceos, obovados ou elípticos, planos, centrais 9,1-12,2 cm compr., 5,4-8,0(10,3) cm larg. com peciólulos 2,1-4,8 cm compr., progressivamente menores em direção à base, ápice retuso ou arredondado, base truncada a cordada, concolores, face abaxial pubescente, com tricomas estrelados, esbranquiçados e persistentes, adaxial glabrescente, venação broquidódroma, margem inteira, não revoluta; pecíolo 5,5-12,3 cm compr., coberto por tricomas estrelados. Inflorescência botrióide, globosa, congesta, com eixo principal curto, terminal ou axilar. Cálice amarelo-esverdeado, irregular e curtamente partido, 1,2-1,5 cm compr., 0,5-0,6 cm larg., viloso, com tricomas simples e estrelados, sem glândulas; corola amarelo brilhante com nervuras vináceas, tubo 4,1-7,3 cm compr., 0,7-2,3 cm larg. na região mediana, face externa glabra, interna pubérula, com tricomas simples e estrelados; ovário pubérulo. Fruto ocráceo, 16,5-25,5 cm compr., 1,0-2,2 cm larg., tomentoso.

Material examinado: BAHIA: Sítio Contagem, estrada entre Abaíra e Catolés, ca. 16 km de Catolés, próximo a Baixa da Onça, col. W. Ganev 860, 15.VIII.1992, fl. (SPF). MINAS GERAIS: Grão-Mogol, bacia do Córrego Escurona, col. J.R. Pirani et al., CFCR 11349, 02.XI.1987, fr. (K, MO, SPF); idem, vale do rio Itacambiruçu, col. I. Cordeiro \& R. Mello-Silva, CFCR 10131, 05.IX.1986, fl. (MBM, SPF); idem, col. J.R. Pirani et al., CFCR 10131, 05.IX.1990, fl. (BHCB, MO, SPF); Serra do Ambrósio, col. T.B. Cavalcanti et al., CFCR 10222, 08.IX.1986, fl. (F, MBM, MO, SPF); Joaquim Felício, col. T.S.M. Grandi s.n., 28.VIII.1988, fl. (BHCB 13618); Montes Claros, col. T.S.M. Grandi et al. s.n., 26.VIII.1988, fl. (BHCB 13540); Bocaiúva, col. T.S.M. Grandi et al. s.n., 28.VIII.1988, fl. (BHCB 13513); Diamantina, col. R.M. Harley et al. 24983, fl. (SPF); idem, estrada para Conselheiro Mata, col. R. Mello-Silva \& J.R. Pirani, CFCR 11032, 18.VII.1987, estéril (MO, SPF); Gouveia, col. J.R. Pirani, CFCR 165, 19.VII.1980, fl. (SPF); Lagoa Santa, col. I.R. Andrade s.n., 07.IX.1987, fl. (BHCB 11043); Serra do Cipó, estrada para o IBAMA, col. L.G. Lohmann et al. 36, 3.IX.1995, fl. (SPF); idem, estrada para o IBAMA, col. L.G. Lohmann et al. 39, 3.IX.1995, fl. (SPF); idem, caminho da base do IBAMA para o Capão dos Palmitos, col. J.R. Pirani et al., CFSC 11970, 25.III.1991, estéril (SPF); idem, Santana do Riacho, rodovia Belo Horizonte-Conceição do Mato Dentro, km 104, col. R. Mello-Silva et al., CFSC 9805, 04.V.1986, estéril (MO, SPF); km 107, caminho para Usina Dr. Pacífico Mascarenhas, col. E. Forero et al., CFSC 9004, 7.IX.1980, fl. (SP); idem, córrego Brauninha, col. M.T.V.A. Campos et al., CFSC 13216, 21.VII.1993, fl. (SPF); idem, col. L.G. Lohmann \& A. Conceição 49, 4.IX.1995, fl. (SPF); idem, col. L.G. Lohmann et al. 54, 4.IX.1995, fl. (SPF); Santa Luzia, col. Mello Barreto 2036, 02.IX.1933, fl. (RB); Santa Bárbara, col. J.R. Stehmann \& G. Pedralli s.n., X. 1987, fr. (BHCB 11205); próximo ao Caraça, col. M.M.N. Braga et al. 244, 7.X.1988, estéril (BHCB); Brumadinho, Serra da Calçada, col. L.A. Martens 133, 12.IX.1989, fl. (SPF); Pico do Itabirito, col. W.A. Teixeira s.n, 22.IX.1994, fl. (BHCB 26289).

Gentry (1992) reconheceu 3 subespécies em T. ochracea de acordo com sua 
distribuição geográfica e indumento do cálice. Na Cadeia do Espinhaço ocorre apenas Tabebuia ochracea ssp. ochracea.

É um elemento típico dos cerrados do Brasil central e regiões adjacentes, também ocorrendo fora do cerrado mas raramente em florestas (Gentry 1992). Na Cadeia do Espinhaço, ocorre em solo arenoso fino, entre rochas, em áreas de transição entre cerrado e campo rupestre, em carrasco, em vegetação rupícola e em mata. Foi encontrada florescendo de março a novembro e frutificando em outubro e novembro.

\subsection{Tabebuia bureavii Sandwith, Kew Bull. 1958 : 442.1959.}

Figs. 8 A-E

Árvore até $12 \mathrm{~m}$ alt.; ramos pubérulos. Folhas 5-folioladas; folíolos cartáceos, elípticos, centrais 5,6-12,0 cm compr., 2,1-5,5 cm larg. com peciólulos 3,4-5,5 cm compr., progressivamente menores em direção à base, ápice acuminado ou apiculado, base arredondada, concolores, face abaxial pubérula, adaxial glabra, venação craspedódroma, margem conspicuamente serreada, não revoluta; pecíolos $6,4-8,0 \mathrm{~cm}$ compr., glabros ou pubérulos. Inflorescência tirsóide, com eixo principal alongado, terminal. Cálice verde com lobos amarelos, irregularmente partido, 1,5-1,6 cm compr., densamente estrelado-pubescente, sem glândulas; corola amarela com estrias douradas na fauce, tubo 3,5-4,7 cm compr., 1,3-2,0 cm larg. na região mediana, tubo glabro em ambas as faces, pubérula na fauce e vilosa na região de inserção dos estames; ovário lepidoto. Frutos e sementes não vistos.

Material examinado: MINAS GERAIS: Grão-Mogol, vale do Rio Itacambiruçu, col. T.B. Cavalcanti et al. CFCR 8392, 04.IX.1985, estéril (MBM, MO, SPF, UB); idem, morro próximo ao Rio Itacambiruçu, col. D.C.Zappi et al., CFCR 8464, 04.IX.1985, fl. (K, MO, SPF).

Está distribuída pela floresta atlântica do Rio de Janeiro e áreas adjacentes da Serra do Mar, sul de São Paulo, tendo sido principalmente coletada no Pico da Tijuca entre 300-1000 m (Gentry 1992). Na Cadeia do Espinhaço foi ncontrada até o presente apenas em Grão-Mogol, no norte de Minas Gerais, crescendo entre rochas, florescendo e frutificando em setembro.

\subsection{Tabebuia vellosoi Toledo, Arq. Bot. Estado de São Paulo, n.s. 3(1): 34.1952.
Figs. 9 A-F}

Árvores, 1-10 m alt.; ramos jovens cobertos por um pubescência ocrácea, glabrescentes. Folhas 5-7-folioladas; folíolos cartáceos, obovais a elípticos, centrais 10,5-13,0 cm compr., 4,2-6,7 cm larg. com peciólulos 2,7-3,7 cm compr., progressivamente menores em direção à base, ápice arredondado, raramente agudo, base arredondada a truncada, discolores, face abaxial avermelhada, estrelado-pubescente, adaxial verde-oliva, glabra, venação craspedódroma, margem serreada, não revoluta; pecíolo 8,2-12,5 cm compr., com tricomas estrelados ou glabros. Inflorescência tirsóide, globosa, congesta, com eixo principal curto e ramos laterais contraídos, terminal ou axilar. Cálice ocráceo, 3-5-lobado, 0,8-2,3 cm compr., 0,6-1,5 cm larg., densamente 


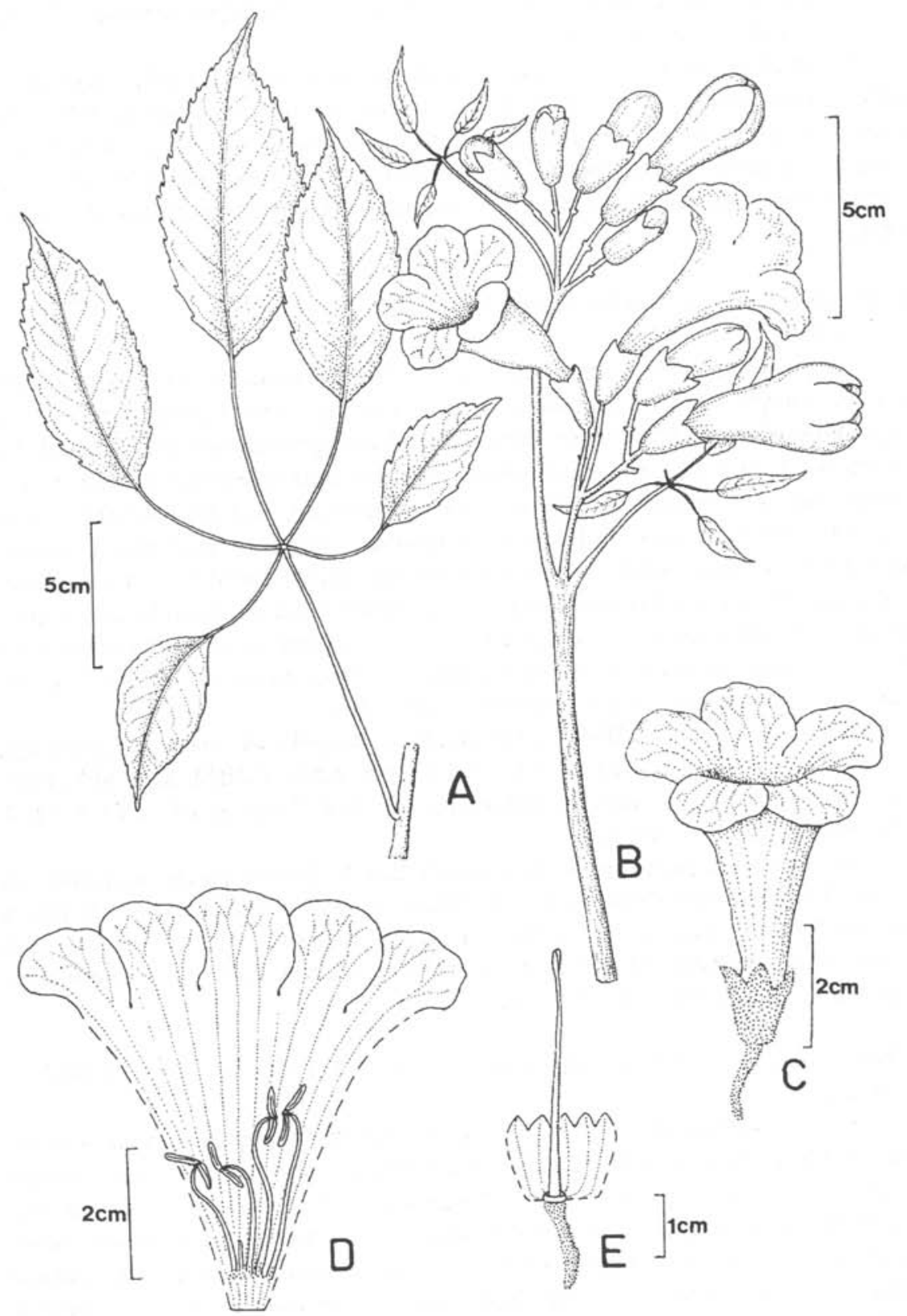

Figura 8. Tabebuia bureavii Sandwith. (CFCR 8464). A: Folha; B: Inflorescência; C: Aspecto geral da flor; D: Corola aberta; E: Cálice aberto mostrando o ovário. 
pubescente, com tricomas simples e estrelados, sem glândulas; corola amarela, tubo $(3,5)$ 4,3-5,7 cm. compr., 0,7-1,1 cm larg. na região mediana, face externa glabra, vilosa na fauce; ovário glabro. Frutos e sementes não vistos.

Material examinado: MINAS GERAIS: Santana do Riacho, Serra do Cipó, rodovia Belo Horizonte-Conceição do Mato Dentro, Córrego Três Pontinhas, col. D.C. Zappi et al., CFSC 10199, 20.VI.1987, fl. (SPF); idem, km 107, col. E. Forero et al., CFSC 8874, 7.IX.1980, fl. (SP,SPF); idem, km 126, col. J. Semir et al., CFSC 4326, 03.IX.1973, fl. (SP); idem, km 129, col. A.B. Joly et al., CFSC 3283, 22.VIII.1972, fl. (SP); idem, próximo a estátua do Velho Juca, col. L.G. Lohmann \& P.H. Silva 40, 3.IX,1995, fl. (SPF); idem, col. J. Semir et al., CFSC 4433, 05.IX.1973, estéril (SP); idem, col. S.P. Ribeiro s.n., 17.VIII.1989, fl. (BHCB 18813); Serra da Bandeirinha, col. L.R. Parra, CFSC 12989, 09.IX.1992, fl. (SPF); Caraça, col. V.L. Scatena s.n., 10.VIII.1987, fl. (BHCB 11782).

A espécie aproxima-se muito de Tabebuia alba, distinguindo-se desta, segundo Gentry (1992), basicamente pelos tricomas avermelhados da face abaxial dos folíolos, em oposição aos densos tricomas esbranquiçados da mesma região em T. alba. No entanto, tal caráter mostrou-se extremamente variável no material observado, sendo os espécimes estudados distintos exclusivamente pelos caracteres apresentados na chave aqui proposta.

Segundo Gentry (1992), T. vellosoi está distribuída do Paraná até Minas Gerais e Rio de Janeiro, principalmente em floresta montana, acima de $1000 \mathrm{~m} \mathrm{s.m.} \mathrm{Na}$ Cadeia do Espinhaço possui habitats bastante diversificados, sendo encontrada no interior e borda de matas ripárias, brejos e cerrados, florescendo de agosto a setembro.

\subsection{Tabebuia alba (Cham.) Sandwith, Lilloa 14:136.1948.}

Figs. 9 G-N

Árvores, 0,4-5,0 m alt.; ramos glabrescentes, jovens densamente cobertos por indumento ocráceo. Folhas 5-6-folioladas; folíolos cartáceos, obovais ou elípticos, planos, centrais 11,2-18,7 cm compr., 6,9-10,7 cm larg. com peciólulos 3,0-3,9 cm compr., progressivamente menores em direção à base, ápice agudo ou acuminado, base arredondada a truncada, fortemente discolores, face abaxial densamente pubescente e esbranquiçada, com glândulas plateliformes próximas a nervura principal, adaxial verde-escura e glabra, venação craspedódroma, margem conspicuamente serreada, não revoluta; pecíolos 7,5-10,5 cm compr., ocráceo-pubescentes. Inflorescência tirsóide, laxa, com eixo principal curto e ramos laterais alongados, terminal. Cálice ocráceo, irregularmente partido, 1,8-2,9 cm compr., 0,9-1,4 cm larg., viloso, coberto por tricomas simples e estrelados, sem glândulas; corola amarela, tubo 4,2-5,5 $\mathrm{cm}$ compr., 1,3-2,8 cm larg. na região mediana, face externa glabra, vilosa na fauce; filete alvo; estiletealvo, ovário finamente lepidoto. Frutos e sementes não vistos.

Material examinado: MINAS GERAIS: Santana do Riacho, Serra do Cipó, idem, rodovia Belo Horizonte-Conceição do Mato Dentro, km 127, col. D. Zappi \& C. Kameyama, CFSC 9871, 02.IX.1986, fl. (SPF); idem, próximo a estátua do Velho Juca, col. L.G. Lohmann et al. 41, 3.IX.1995, fl. (SPF); idem, próximo a estátua do 


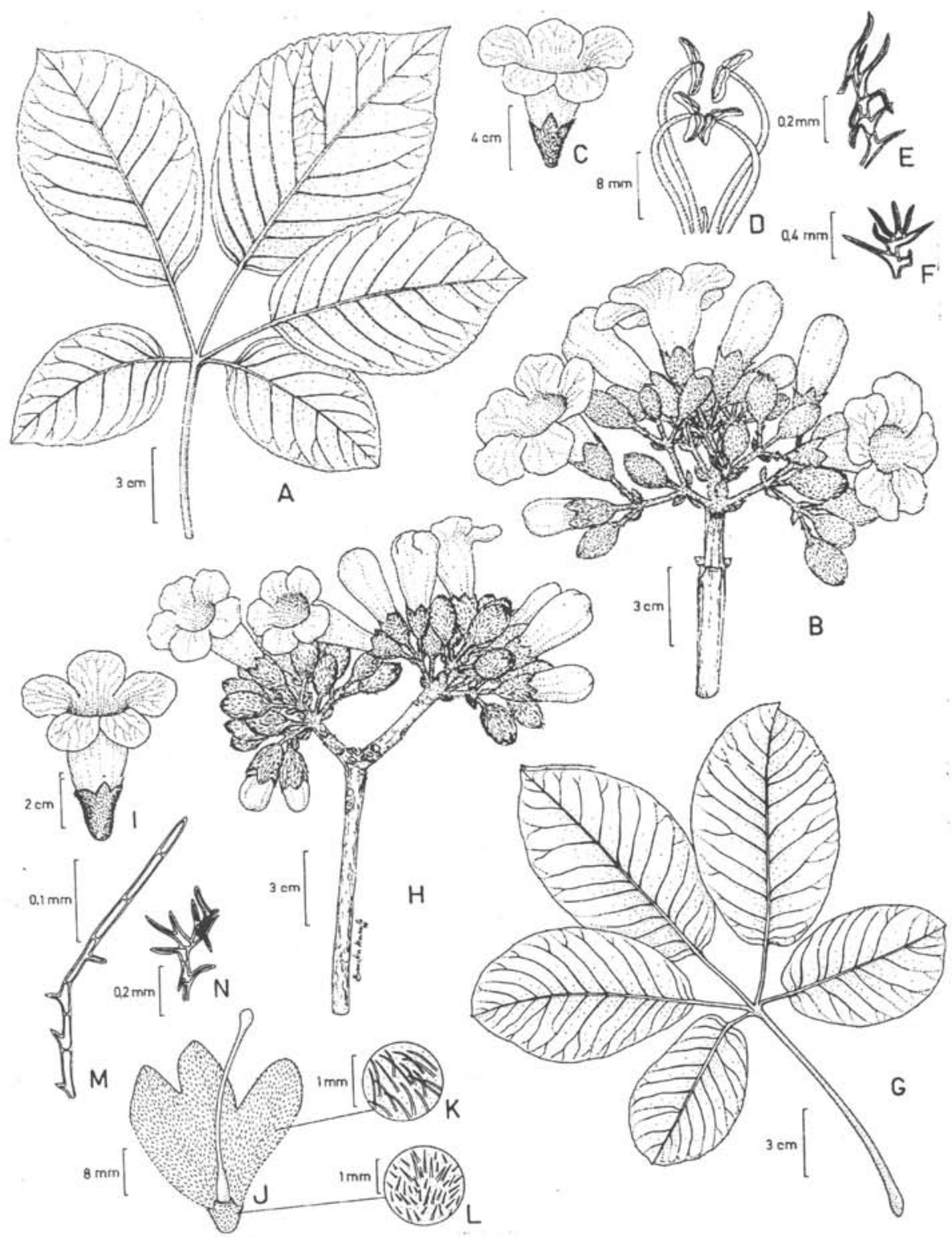

Figura 9. A-F: Tabebuia alba (Cham.) Sandwith. A: Folha (CFSC 4871); B: Inflorescência (CFSC 10502); C: Aspecto geral da flor (CFSC 10502); D: Detalhe dos estames e estaminódio (CFSC 10502); E: Detalhe de tricomas do cálice (CFSC 10502). G-N: Tabebuia vellosoi Toledo. G: Folha (CFSC 8874); H: Inflorescência (CFSC 8874); I: Aspecto geral da flor (CFSC 4326); J: Cálice aberto mostrando o ovário (CFSC 3283); K: Detalhe dos tricomas da face externa do cálice; L: Detalhe dos tricomas da face interna do cálice; M e N: Detalhe de tricomas do cálice (CFSC 3283). 
Velho Juca, col. L.G. Lohmann 42, 3.IX.1995, fl. e fr. (SPF); Serra da Bandeirinha, ca. $1200 \mathrm{~m}$ alt., col. C. Kameyama et al., CFSC 10502, 09.IX.1987, fl. (SPF); idem, col. L. Lohmann \& J.R. Pirani, CFSC 13082, 02.V.1993, estéril (SPF); idem, col. S.P. Ribeiro S.n., 17.VIII.1989, fl. (BHCB 18815); Serra do Ouro Branco, col. M.M.N. Braga 208, fl. (BHCB); idem, col. M.T.D. Almeida et al. s.n., 01.X.1988, fr. (BHCB 14095); idem, col. M.M.N. Braga et al. 265, 21.X.1988, fr. (BHCB).

Esta espécie ocorre de Minas Gerais e Rio de Janeiro até Rio Grande do Sul e Missiones (Argentina), geralmente em florestas subtropicais, especificamente na zona de araucária, entre 300 e 1000 m s.m. (Gentry 1992). Na Cadeia do Espinhaço foi ncontrada até o presente apenas na Serra do Cipó, em campo de solo ncharcado e à beira da mata de encosta, florescendo de julho a setembro, após a queda das folhas e frutificando em outubro.

\section{Zeyheria Mart.}

Arbustos a árvores. Folhas digitadas, 3-5-folioladas, persistentes, raque nunca alada. Inflorescência dicotomicamente ramificada. Cálice campanulado, profundamente 2-4-lobado, geralmente bilabiado até próximo a base, coriáceo, face externa densamente estrelado-tomentosa, interna glabra, pubérula na região de inserção dos estames, lobos estreitos; corola ocrácea, com a face interna amarelada a laranja escuro ou arroxeado, tubular, coriácea; anteras bitecas, densamente tomentosa externamente; estaminódio reduzido, glabro ou pubérulo; ovário globoso a elipsóide, densamente estrelado-piloso, óvulos multisseriados em cada lóculo; disco nectarífero anular. Cápsula arredondada ou ovóide, volumosa, ocrácea, densamente tomentosa, muricada. Sementes finas, com alas membranáceas. nhaço.

Gênero neotropical com 2 espécies, ambas representadas na Cadeia do Espi-

Chave para as espécies de Zeyheria do Espinhaço

1'. Folíolos coriáceos, face abaxial creme com venação terciária obscura pelo indumento; corola tubular-cilindrica, maior que $2,2 \mathrm{~cm}$ compr.; cerrados.

1. Folíolos cartáceos, face abaxial acinzentada com venação terciária aparenZ. montana te; corola largamente campanulada, menor que $1,5 \mathrm{~cm}$ compr.; florestas decíduas Z. tuberculosa

\subsection{Zeyheria montana Mart., Nov. Gen. Sp. Pl 6: 66. 1826.}

Figs. $10 \mathrm{~A}-\mathrm{F}$

Arvoreta ou arbustos, 1,0-4,5 m alt.; ramos ocráceo-pubescentes. Folhas 5folioladas; folíolos coriáceos, oblongo-ovais ou estreitamente elípticos, planos a suavemente bulados, centrais 5,7-18,2 cm compr., 1,6-6,2 cm larg. com peciólulos 0,2-1,7 cm compr., progressivamente menores em direção a base, ápice agudo ou arredondado, às vezes obtuso quando jovem, base cuneada, discolores, face abaxial creme, estrelado-tomentosa, adaxial glabra, oliva escuro, venação broquidódroma, 
terciárias obscuras pelo indumento, margem inteira, suavemente revoluta; pecíolo 4,2$14,3 \mathrm{~cm}$ compr., com estrias longitudinais. Inflorescência em tirso, terminal. Cálice creme, 2-4-partido até a região mediana, 1,1-1,7 cm compr., 0,8-1,3 cm larg., densamente estrelado-tomentoso; corola ocrácea, amarela internamente, tubular-cilíndrica, com tubo 2,2-3,5 cm compr., 0,8-1,3 cm larg. na região mediana, face externa densamente tomentosa, com tricomas simples e estrelados, interna glabra, vilosa na região de inserção dos estames; ovário coberto por tricomas estrelados. Cápsula arredondada ou ovóide, ocrácea, 2,5-8,2 cm compr., 1,5-5,5 cm larg., densamente tomentosa, muricada.

Material examinado: BAHIA: Serra Geral de Caitité, col. R.M. Harley 21102, 9.IV.1980, fl. (K, SPF); estrada entre Mucugê e Abaíra, ca. 42 km de Mucugê, próximo ao Brejo de Cima, col. W. Ganev 841, 13.VIII.1992, fl. (K, SPF); estrada entre Mucugê e Abaíra, 40 km de Abaíra, col. W. Ganev 125, 13.IV.1992, fl. (K, SPF); estrada entre Catolés de Cima e Campo Grande, col. W. Ganev 1005, 3.IX.1992, fl. (K, SPF); Pico das Almas, col. R.M. Harley 19593, 17.II.1977, fl. (K, SPF). MINAS GERAIS: Grão-Mogol, col. G. Martinelli et al. 11197, 20.VII.1985, fl. (BHCB); idem, adjacências do córrego Escurona, col. J.R. Pirani et al., CFCR 13178, 16.VI.1990, fl. fr. (MO, SPF); Serra do Cabral, col. M.M. Arbo et al. 4578, 20.V.1990, fl. (CTES, SPF); Jambeiro, col. H.C. de Lima et al. 1002, 10.V.1979, fl. (R); Diamantina, col. J.R. Pirani \& R. Mello-Silva, CFCR 12195, 21.III.1989, fl. (SPF); idem, col. C. Kameyama \& G.L. Esteves 36, 20.III.1993, fl. (SPF); idem, Mineração Tejucana, col. L.V. Costa et al. 470, IV.1989, fl. (BHCB); Congonhas do Norte, Retiro do Barbado, morro à esquerda do Rio Preto, col. A. Furlan et al., CFSC 8370, 22.IV.1982, fl. (SP, SPF); Conceição do Mato Dentro, córrego Santo Antônio, col. A. Furlan et al., CFCR 720, 12.IV.1981, fl. (SPF); Santana do Riacho, Serra do Cipó, estrada que leva à sede do IBAMA, col. F.A. Vitta \& T.R. Silva, CFSC 13019, 18.II.1993, fl. (SPF); idem, ao longo da rodovia Belo Horizonte-Conceição do Mato Dentro, km 3, col. M.M. Arbo et al. 4730, 09.II.1991, fl. (CTES, SPF); km 105, col. N.M. Castro \& S. Mayo, CFSC 7199, 03.III.1981, fl. (SP, SPF); idem, km 106, col. N.S. Chukr et al., CFSC 9700, 03.V.1986, fl. (SPF); km 56, col. L.B. Smith 6958, estéril (R); 0,6-1 km da pensão Chapéu de Sol, col. G.L. Esteves, W. Morawetz \& B. Wallnöfer, CFCR 15460, 19.IX.1990, fr. (SPF); Chapéu de Sol, col. L.B. Smith 6999, 29.IV.1952, fl. (R); idem, km 107, caminho para Usina Dr. Pacífico Mascarenhas, col. E. Forero et al., CFSC 9014, 7.IX.1980, fl. fr. (SP); idem, col. L.G. Lohmann et al. 50, 4.IX.1995, fr. (SPF); idem, col. L.G. Lohmann et al. 51, 4.IX.1995, fl. \& fr. (SPF); idem, col. I. Cordeiro, J.R. Pirani \& A. Furlan, CFSC 6135, 25.V.1980, fl. fr. (SP, SPF); idem, col. F. Atala, 05.IV.1958, fl. (R); idem, col. P.M. Andrade \& M.A. Lopes s.n., 15.IV.1985, fl. (BHCB 17532); idem, col. J.A. Lombardi \& F.R.N. Toledo 197, fl. (BHCB); idem, col. J.A. Lombardi \& F.R.N. Toledo 441, 24.IX.1993, fr. (BHCB); idem, col. F. Atala 218, 04.IV.1958, fl. (R); Lagoa Santa, col. L.B. Smith 6722, 30.IV.1952, fl. (R); idem, col. Mello Barreto 138, 23.VII.1932, fl. (R); idem, col. T.S.M. Grandi s.n., 25.VIII.1989, fl. (BHCB 18013); idem, col. J.A. Lombardi \& F.R.N. Toledo 40, 12.VIII.1993, fr. (BHCB); Santa Luzia, col. Mello Barreto 849, 5.VIII.1933, fr. (BHMH); idem, col. 


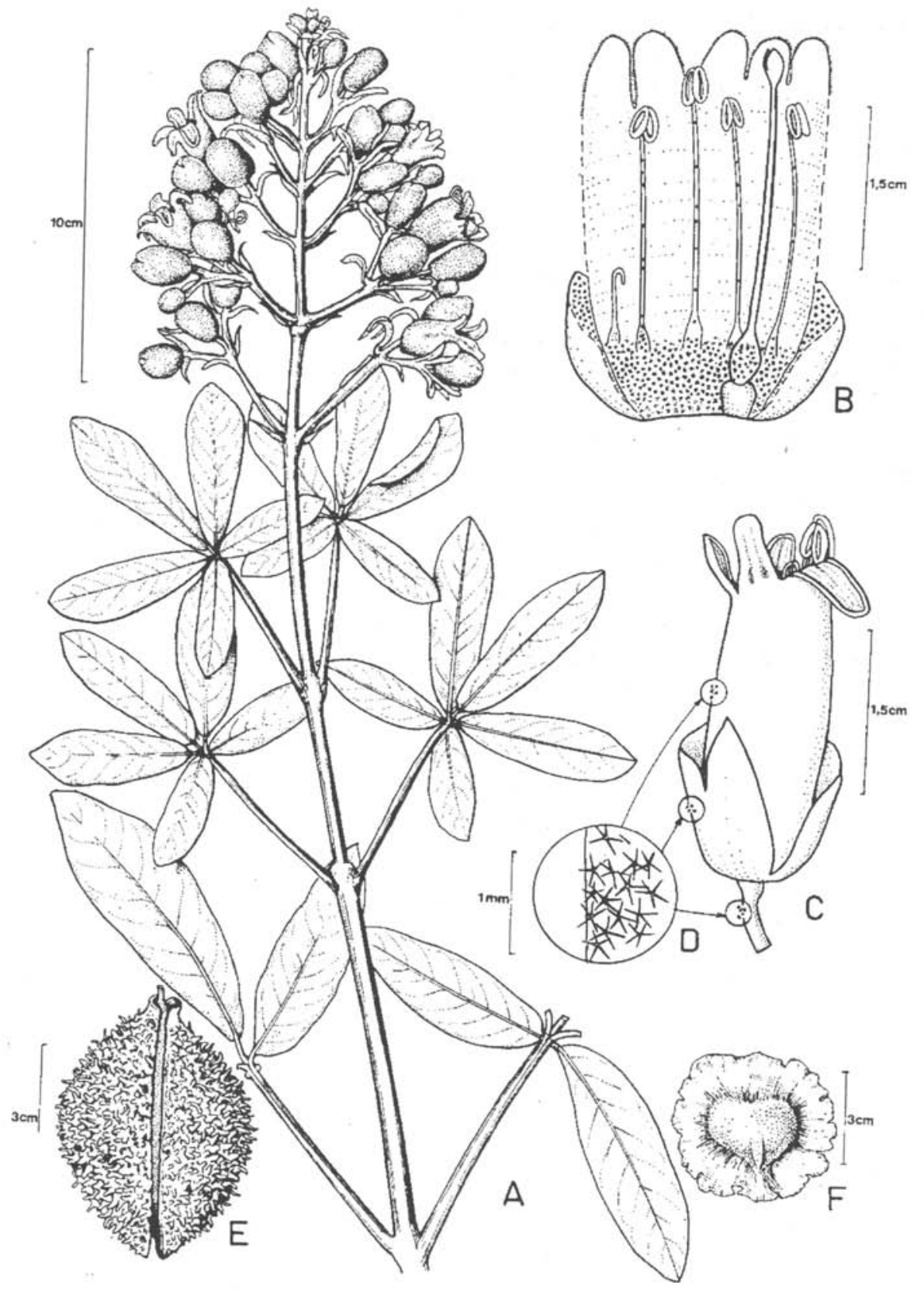

Figura 10. Zey/heria montana Mart. A: Ramo (CFSC 9700); B: Corola aberta (CFSC 8370); C: Aspecto geral da flor (CFSC 8370); D: Detalhe dos tricomas estrelados da flor; E: Fruto; F: Semente. 
Mello Barreto 844, 28.V.1933, fl. (BHMH); Morro do Chapéu, Nova Lima, col. T.S.M. Grandi \& P.M. Andrade 976, 28.IV.1982, fl. (BHCB); Serra do Taquaril, col. Mello Barreto 838, 7.II.1933, fl. (BHMH); Brumadinho, Serra da Calçada, col. L.A. Martens, 04.III.1989, fl. (SPF); Pico do Itabirito, col. W.A. Teixeira, 05.III.1995, fl. (BHCB 26527); Serra da Mutuca, col. Mello Barreto 8709, 30.IX.1938, fr. (BHMH).

Zeyheria montana caracteriza-se pelos folíolos coriáceos fortemente discolores e pela corola tubular-cilíndrica, densamente tomentosa.

Está distribuída pelo planalto central brasileiro, ocorrendo no cerrado e formações a ele ligadas, entre 350-1000 m s.m. (Gentry 1992). Na Cadeia do Espinhaço é realmente comum em campos rupestres com solo areno-pedregoso, em cerrados e em campo limpo, principalmente nas Serras de Minas Gerais. Foi encontrada com flores de fevereiro a agosto e com frutos em abril, junho, agosto, setembro e novembro.

4.2. Zeyheria tuberculosa (Vell.) Bur., Vidensk. Meddel. Dansk. Naturhist. Foren. Kjobenhavn 1893:115. 1893.

Figs. 11 A-D

Árvore até 6,0 m alt.; ramos com tricomas estrelados marrom-escuros. Folhas 5folioladas; folíolos cartáceos, elípticos a obovais, centrais 6,0-12,7 cm compr., 2,8-3,9 cm larg. com peciólulos 1,6-3,2 cm compr., progressivamente menores em direção a base, ápice acuminado, base truncada ou cordada, discolores, face abaxial acinzentada, estrelado-tomentosa e lisa, adaxial oliva escuro e rugosa, venação eucamptódro$\mathrm{ma}$, terciárias proeminentes na face abaxial, margem inteira a suavemente denteada, não revoluta; pecíolos 14,5-20,0 cm compr. Inflorescência em tirso, terminal. Cálice marrom escuro, partido até a base, 0,3-,0,6 cm compr., 0,3-0,5 cm larg., tomentoso; corola largamente campanulada, tubo $0,8-1,5 \mathrm{~cm}$ compr., 0,7-1,1 cm larg., com tricomas marrom escuros na face externa, face interna amarela; ovário piloso-estrelado. Frutos e sementes não vistos.

Material examinado: BAHIA: Serra do Sincorá, 15 a 20km de Andaraí, col. R.M. Harley et al. 18645, 13.II.1977, fl. (K, SPF). MINAS GERAIS: Fazenda da Mãe d'Água, col. A.P. Duarte 7412, 25.XI.1962, fl. (RB).

Segundo Gentry (1992), ocorre na Mata Atlântica do sudeste do Brasil, de São Paulo a Pernambuco, entre 50-1000 m s.m., sendo aparentemente disjunta no Mato Grosso do Sul e na Bolívia. Na Cadeia do Espinhaço foi ncontrada em floresta secundária densa, próxima a um córrego, em solo laterítico. Foi coletada com flores em fevereiro.

\section{Discussão e conclusões}

Dos 20 gêneros da Tribo Tecomeae, 4 são encontrados na Cadeia do Espinhaço: Cybistax, Jacaranda, Tabebuia e Zeyheria.

O gênero Zeyheria possui apenas duas espécies bem distintas, ambas ocorrendo na região. Z. montana Mart. é arbusto ou arvoreta bem representada nos cerrados enquanto Z. tuberculosa (Vell.) Bur. é árvore florestal mais rara. 


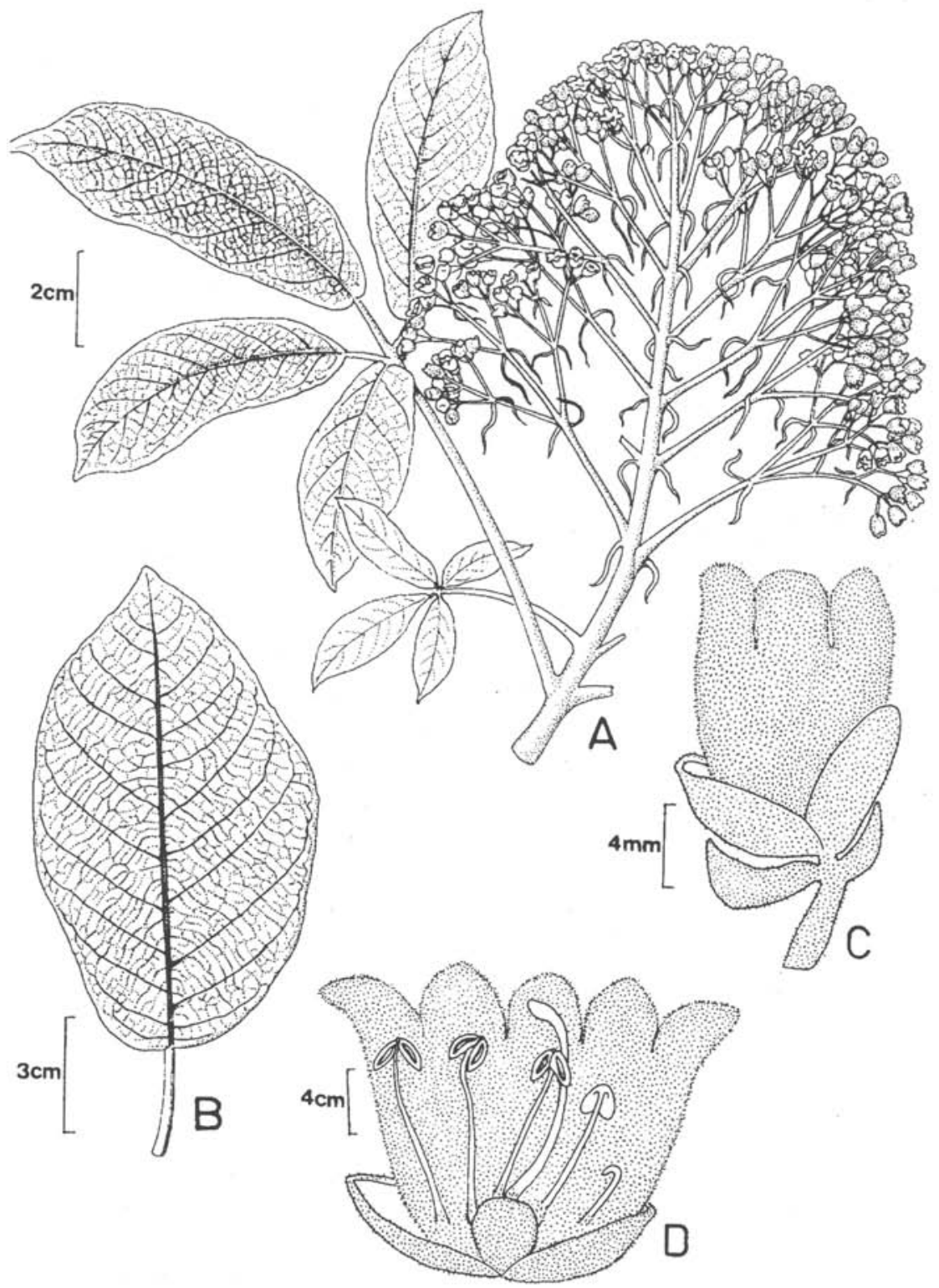

Figura 11. Zeyheria tuberculosa (Vell.) Bur. A: Ramo (Harley 18645); B: Folíolo (Fagundes 2207); C: Aspecto geral da flor (Fagundes 2207); D: Flor aberta (Fagundes 2207). 
O gênero Tabebuia está representado por 1 única espécie arbustiva, T. pumila A. Gentry, e por 5 espécies arbóreas, T. bureavii Sandwith, T. aurea (Manso) Benth. \& Hook. e $T$. oćhracea Cham. são bem características e de fácil identificação na área de estudo. T. bureavii destaca-se pelos folíolos concolores, conspicuamente serreados. T. aurea é espécie típica do cerrado com ramos tortuosos e a única espécie da tribo na região a apresentar folíolos glabros e cálice lepidoto. T. ochracea é uma espécie polimórfica, com populações alopátricas em diferentes partes da América tropical consideradas como subespécies e mantidas na mesma espécie pelo cálice viloso, pelo fruto tomentoso, pelo indumento dos folíolos e pela presença de tricomas estrelados no cálice e corola. A densidade do indumento das folhas neste táxon varia geograficamente e é importante característica na separação das subespécies. Apesar da recente revisão da tribo (Gentry, 1992), foram encontrados problemas taxonômicos na circunscrição de T. alba (Cham.) Sandwith. e T. vellosoi Toledo, que ocorrem simpatricamente na área e exibem formas intermediárias.

Jacaranda é o gênero de maior diversidade na região, estando representado por 8 espécies. Problemas taxonômicos foram encontrados na distinção entre $J$. oxyphylla Cham. e J. caroba (Vell.) DC. Gentry \& Morawetz (1992) as consideram espécies distintas com base na ecologia e dimensões dos folíolos. No entanto, pudemos observar que tais características não se mostraram consistentes para o reconhecimento de dois táxons. Seguimos portanto, o tratamento mais antigo de Bureau \& Schumann (1897), reconhecendo apenas uma espécie, J. caroba. Outro problema taxonômico está na constatação dos caracteres que distinguem $J$. puberula Cham. e J. caroba. Segundo Gentry (1992) estas distinguem-se principalmente pelo indumento dos folíolos. No entanto, no material examinado, tais espécies não apresentaram variação na pilosidade, mas por outro lado distinguiram-se pelo hábito e margem dos folíolos, denteada em J.puberula e inteiros em J. caroba.J. brasiliana (Lam.) Pers. possui os maiores frutos da tribo, sendo estes lenhosos e com margens onduladas. J. irwinii Gentry e J. paucifoliolata Mart. ex DC. são espécies muito próximas, diferindo principalmente pelos caracteres apresentados na chave (hábito, número e margem dos folíolos e cálice).

O estudo da distribuição geográfica mostrou que a maioria das espécies da tribo estudadas apresenta ampla distribuição, sendo poucas raras ou endêmicas do Espinhaço.

T.ochracea subsp.ochracea, Z.montana e J.brasiliana restringem-se ao território brasileiro, estando distribuídas por muitos estados. As duas primeiras concentramse principalmente nos cerrados do Brasil central e regiões adjacentes e a terceira ocorre também m florestas de galeria. T.aurea é também spécie comum no cerrado brasileiro, mas é ncontrada também na Bolívia, Argentina e Suriname, conforme já mostrou Gentry (1992).

J.caroba e J.puberula, espécies com características morfológicas muito próximas, distribuem-se pelas regiões sul, sudeste e centro-oeste do Brasil. A primeira restringe-se ao Paraná, São Paulo, Minas Gerais, Goiás e Distriro Federal e a segunda, com distribuição um pouco mais ampla, estende-se desde Missiones (Argentina) e Rio Grande do Sul até a Bahia, Pernambuco e costa do Ceará.

T.alba é espécie amplamente distribuída pelo sudeste brasileiro, ocorrendo $\mathrm{m}$ 
florestas do Rio Grande do Sul, Minas Gerais e Rio de Janeiro, e em Missiones, na Argentina.

Entre as espécies de distribuição mais restrita estão: T.vellosoi, restrita ao sudoeste de Minas Gerais, Rio de Janeiro e Paraná; T.bureavii, ocorrendo apenas na floresta atlântica do Rio de Janeiro, áreas adjacentes da Serra do Mar, sul de São Paulo e aparentemente disjunta em Grão-Mogol; J.irwinii restrita ao centro-oeste da Bahia; J.paucifoliolata exclusiva de Minas Gerais e Goiás.T.pumila e J.racemosa Cham.são endêmicas dos campos rupestres da Cadeia do Espinhaço, em Minas Gerais. J.pulcherrima Morawetz ocorre nas terras altas do sudeste de Minas Gerais e serras adjacentes de São Paulo e Rio de Janeiro.

J.ulei Bur. \& K.Schum. exibe uma curiosa disjunção, sendo conhecida apenas da região central de Goiás, noroeste de Minas Gerais, centro da Bahia e dos afloramentos férricos da Serra dos Carajás, no Pará. Z.tuberculosa, apesar de anteriormente referida como uma possível espécie disjunta na Bolívia (Gentry 1992), teve esta disjunção atenuada pelo exame de coleções provenientes do Mato Grosso do Sul.

Embora possa ser conseqüência de falta de coletas, algumas das espécies de distribuição relativamente ampla foram encontradas no Espinhaço restritas a apenas uma serra, como é o caso de T.vellosoi e T.alba, com populações numerosas na Serra do Cipó e T.bureavii Sandwith, rara e apenas em Grão-Mogol.

\section{Referências bibliográficas}

Abreu, A.A., 1984. O planalto de Diamantina: um setor da Serra do Espinhaço em Minas Gerais. Orientação - Instituto de Geografia, USP, 5: 75-79.

Bureau, L.E. \& Schumann, K.M. 1897. Bignoniaceae. In Martius, C. F. P. (ed.). Flora Brasiliensis 8(2): $1-451$.

Galvão M.Y. \& Nimer, E. 1965. Clima. In IBGE Geografia do Brasil - Grande Região Leste. IBGE. Rio de Janeiro, 5 (19): 91-139.

Gentry, A.H. 1980. Bignoniaceae Part I - Tribes Crescentieae and Tourretieae. Flora Neotropica 25(1): 1130.

Gentry, A.H. 1992. Bignoniaceae Part II - Tribe Tecomeae. Flora Neotropica 25(2): 1-362.

Gentry, A. \& Morawetz, W. 1992. Jacaranda. In Gentry, A. Bignoniaceae Part II - Tribe Tecomeae. Flora Neotropica 25(2): 51-105.

Gentry, A., Semir, J. \& Gabrielli, A.C. 1987. Bignoniaceae. In Giulietti, A.M. et al. Flora da Serra do Cipó, Minas Gerais: Caracterização e lista das espécies. Bolm. Bot. Univ. S. Paulo, 9: 1-151.

Giulietti, A.M. \& Pirani, J.R. 1988. Paterns of geographic distribution of some plant species from the Espinhaço Range, Minas Gerais and Bahia, Brasil. In Vanzolini, P.E.A. Heyer, (eds) Proceedings of a Workshop on Neotropical Distribution Patterns, p. 39-69.

Harley, R.M. \& Simmons, N.A. 1986. Florula de Mucugê, Chapada Diamantina-Bahia, Brazil. Royal Botanic Gardens. Kew.

Joly, A.B. 1970. Conheça a vegetação brasileira. EDUSP e Polígono. São Paulo.

King, L.C. 1956. A geomorfologia do Brasil Oriental. Revta. brasil. Geogr., 18:147-265.

Köppen, W. 1931. Climatologia. Fondo de Cultura Economica, Buenos Aires.

Magalhães, G.M. 1966. Sobre os cerrados de Minas Gerais. An. Acad. Bras. Ciênc. 38 (supl.): 59-70.

Magalhães, G.M. 1954. Contribuição para o conhecimento da flora dos campos alpinos de Minas Gerais. In Anais V Congresso Nacional de Botânica, Porto Alegre. Sociedade Botânica do Brasil, p. 227-304.

Meguro, M., Pirani, J.R., Giulietti A.M., Mello-Silva, R. Phytophysionomy and composition of the 
vegetation of Serra do Ambrósio, Minas Gerais, Brazil. 1994. Revta. bras. Bot. 17 (2): 149-166. Moreira, A.N. 1977. Relevo. In IBGE. Geografia do Brasil. Vol 2. Região Nordeste. Rio de Janeiro, p. 1-45.

Pirani, J.R., Giulietti, A.M., Mello-Silva, R. \& Meguro, M., 1994. Checklist and patterns of geographic distribution of the vegetation of Serra do Ambrósio, Minas Gerais, Brazil. Revta. bras. Bot. 17 (2): 133-147.

Weberling, F. 1989. Morphology of flowers and inflorescences. Cambridge University Press. 